\title{
ARTICLES
}

\section{A GUIDE TO THE GOP TAX PLAN - THE WAY TO A BETTER WAY}

\author{
David A. Weisbach*

\section{Executive Summary}

The tax reform plan - A Better Way - put forward by the chairman of the House Ways and Means Committee Kevin Brady and the Speaker of the House, Paul Ryan would be the most substantial tax reform in the United States since the enactment of the income tax in 1913. At the corporate level, the reform would allow immediate expensing of investments, deny deductions for net interest expense, and eliminate the taxation of income from sales in foreign countries while taxing the full value of imports (together shifting the tax base to a destination basis). At the individual level, the system would tax capital income including interest, dividends, and capital gains at half the rate that wages and salaries are taxed. It would also repeal the estate and generation skipping taxes. These changes would go a long way toward shifting the tax system to taxing consumption rather than income.

This paper considers the implementation of the House GOP tax plan and addresses issues that will need to be resolved if the plan is to work as intended. The plan is based on, and builds off of, a long history of thinking about consumption taxes. To understand the basic choices made in the plan, it is helpful to understand this history and how consumption taxes work in general.

The paper provides a nutshell version of this history. It shows that the plan is essentially the same as the proposal put forward by the tax reform panel convened by President Bush in 2005 known as the

\footnotetext{
* Walter J. Blum Professor, The University of Chicago Law School, and
} Senior Fellow, the University of Chicago Computation Institute and Argonne National Laboratories. Send comments to d-weisbach@uchicago.edu. I thank Alan Auerbach, Peter Daub, Daniel Hemel, Ed Kleinbard, Julie Roin, Steve Shay, Willard Taylor, Al Warren, and workshop participants at the University of Chicago Law School for comments. Disclosure: I was an outside consultant to the President's Advisory Panel on Federal Tax Reform, which proposed a tax reform that closely resembles the GOP plan. 
Growth and Investment Tax. That plan, in turn, was a modification of two similar consumption tax proposals, the Flat Tax and a closely related plan known as the X-tax. And these proposals are modifications of the standard VAT used throughout the world. Understanding how VATs work and the issues they raise, as well as the reason for the various evolutions in the proposals allows us to understand the central issues that will arise in implementing the Brady plan.

After summarizing this history, the paper turns to the issues that will need to be resolved to implement the plan, focusing on eight sets of issues: (i) the design of the business tax; (ii) the relative tax rates for corporations, partnerships, labor income, and the capital income of individuals; (iii) international tax issues; (iv) the taxation of financial instruments and institutions; (v) the taxation of corporate transactions such as mergers and acquisitions; (vi) deferral and the functioning of the individual-level tax on capital income; (vii) issues relating to the individual tax base such as the mortgage interest deduction; and (viii) problems of transition.

Some of the problems in the current draft of the Brady plan, such as inconsistencies in the design of the corporate tax, are easily fixed. Some problems, such as the treatment of pass-through entities and the taxation of major corporate transactions, can be improved with modest substantive changes. Others, such as the taxation of financial institutions, will require substantial effort to get right, but approximate solutions exist. Finally, some issues, such as the taxation of capital income at the individual level, will not be readily fixed. The basic structure of the plan may not be workable for these issues and resolution of these issues might require structural changes to the plan. Overall, I believe that a system following the contours of the House GOP tax plan can be made to work, but solving the implementation problems will take time, effort, and compromises. 


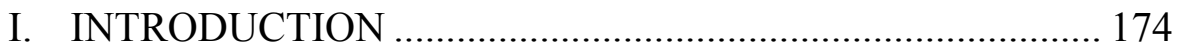

II. DESCRIPTION OF THE PROPOSAL …............................. 176

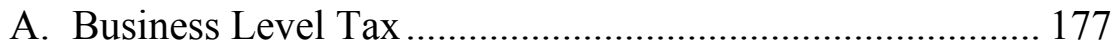

B. International Tax Rules.................................................... 178

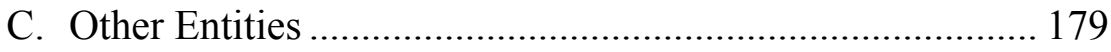

D. Individual Level Taxation................................................. 179

E. Estate and Gift Taxation .................................................... 180

F. Revenue and Distribution .................................................. 180

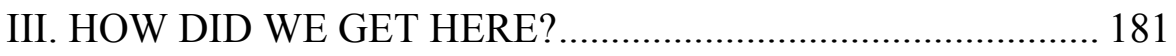

A. Consumption Tax Basics …………………...................... 181

B. The Cash-Flow or Subtraction-Method VAT ..................... 184

C. Destination v. Origin Basis ................................................ 187

D. The Flat Tax and the X-tax ................................................ 191

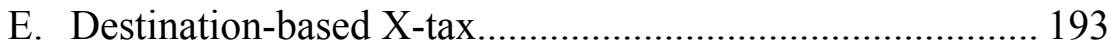

F. The Growth and Investment Tax Plan ................................ 194

G. The Brady Plan ................................................................. 195

IV. ISSUES AND PROBLEMS WITH THE BRADY PLAN....... 195

A. Design of the Business Tax................................................. 196

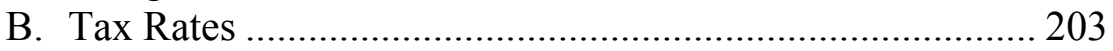

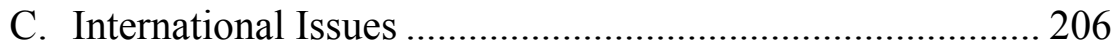

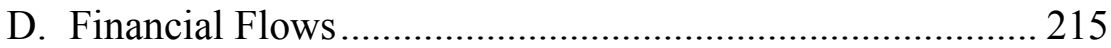

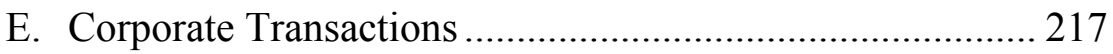

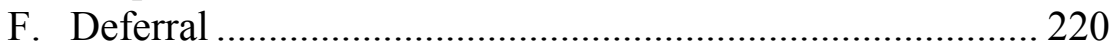

G. Other Individual Tax Provisions........................................... 222

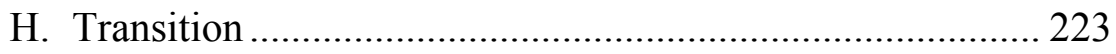

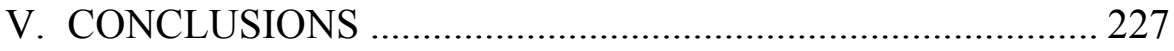




\section{INTRODUCTION}

The tax reform plan put forth by the Chairman of the Ways and Means Committee, Representative Kevin Brady (R-TX) and the Speaker of the House, Paul Ryan (R-WI), if enacted, would be the most substantial tax reform since the original enactment of the income tax in 1913, far exceeding the 1986 reform. ${ }^{1}$ Known as "A Better Way," the plan (which I will call the Brady plan for short) would shift the corporate tax from a tax on income toward a tax on consumption, from a worldwide system to a territorial system on what is called a "destination basis," and from a system that allows a deduction for interest expense to a system that at least to some extent ignores financial flows. ${ }^{2}$ At the individual level, the plan would tax capital income, including interest, dividends, and capital gains, at half of the tax rate on wage income, greatly reducing the tax on capital. Combined, the changes to the corporate tax and the individual tax would transform the tax system, shifting strongly toward a consumption base and away from an income base.

Although it would be a dramatic change from current law, the plan is based on a long line of academic study. It is also based on numerous proposals put forward in the past including a relatively detailed proposal by the tax reform commission created by President Bush in 2005. And it has similarities to consumption tax systems currently in use elsewhere in the world. We know a reasonable amount about how the system should work.

Nevertheless, nothing quite like this has ever been tried in the United States or any other developed country. It would be a massive break from the past. To implement the proposal, we would have to resolve numerous issues, some of which are barely mentioned in the current description of the plan and many of which are not mentioned at all.

${ }^{1}$ A possible rival is the addition of withholding under the income tax during World War II, which effectively converted the income tax from a tax on a small minority of wealthy individuals to a tax on most of the population. A second possible rival would be the gradual expansion of the payroll tax to be the dominant tax paid by a large portion of the population.

${ }^{2}$ The most recent description of the plan can be found at A Better Way (June 24, 2016), http://abetterway.speaker.gov/_assets/pdf/ABetterWay-TaxPolicyPaper.pdf [perma.cc/9Z2N-NE2J].

${ }^{3}$ Simple, Fair, and Pro-Growth: Proposals to Fix America's Tax System, REPORT OF THE PRESIDENT'S ADVISORY PANEL ON FEDERAL TAX REFORM (Nov. 2005), http://www.treasury.gov/resource-center/tax-policy/Documents/Report-FixTax-System-2005.pdf [perma.cc/V6HP-NXPW]. 
My goal in this paper is to provide a guide to the plan, focusing on how the tax system would be implemented rather than the economic and distributional effects. ${ }^{4}$ I start by describing the broad contours of the plan based on what is currently publicly available. As noted, the proposal is based on a long history of study of consumption taxation. To understand the structure and reasons for the choices made in the proposal, I next provide an encapsulated version of the history of thinking about consumption taxes, and show how the plan relates to, and is built off of, prior proposals. ${ }^{5}$ In particular, the Brady plan is essentially the same as the "Growth and Investment Plan" proposed by President Bush's tax reform commission. ${ }^{6}$ That plan itself was built off of a prior proposal by David Bradford known as the X-tax, ${ }^{7}$ and a plan by Robert Hall and Alvin Rabushka, known as the Flat Tax. ${ }^{8}$ These plans in turn are a modifications of a VAT, which is the standard form of consumption taxation used by nations around the world.

After showing how the Brady plan fits into this history, I examine the issues that will need to be resolved if the plan is to be implemented. I focus on eight sets of issues: (i) the design of the business tax; (ii) the relationship between the tax rates for corporations, partnerships, labor income, and the capital income of individuals; (iii) international tax issues; (iv) the taxation of financial instruments and institutions; (v) the taxation of corporate transactions such as mergers and acquisitions; (vi) deferral and the functioning of the individual-level tax on capital income; (vii) issues relating to the

${ }^{4}$ For additional analyses of the plan, see Reuven S. Avi-Yonah \& Kimberly Clausing, Problems with Destination-Based Corporate Taxes and the Ryan Blueprint, 8 COLUM. J. TAX L. 229 (2017); Leonard E. Burman, James R. Nunns, Benjamin R. Page, Jeffrey Rohaly \& Joseph Rosenberg, An Analysis of the House GOP Tax Plan, 8 ColuM. J. TAx L. 257 (2017); Elena Patel \& John McClelland, What Would a Cash Flow Tax Look Like for U.S. Companies? Lessons from a Historical Panel, U.S. DEP'T OF THE TREASURY OFF. OF TAX ANALYSIS (Jan. 2017), http://www.treasury.gov/resource-center/tax-policy/taxanalysis/Documents/WP-116.pdf [perma.cc/273T-WBH5].

${ }^{5}$ The discussion is based largely on two of my prior publications on this topic, David A. Weisbach, Ironing Out the Flat Tax, 52 STANFORD L. REV. 599 (2000), and David A. Weisbach, Does the X-Tax Mark the Spot?, 56 SMU L. REV. 201-238 (2003). supra note 3 .

${ }^{6}$ Simple, Fair, and Pro-Growth: Proposals to Fix America's Tax System,

${ }^{7}$ DAVid F. BRAdFord, Untangling the Income TAX (1986); David F. Bradford, What Are Consumption Taxes and Who Pays Them?, 39 TAX NOTES 383-91 (1988).

${ }^{8}$ Robert Ernest Hall \& Alvin Rabushka, Low Tax, Simple Tax, Flat Tax (1983). 
individual tax base such as the mortgage interest deduction; and (viii) problems of transition.

Some of the problems I discuss can be readily fixed, but many of the issues that need to be resolved are complex and defy easy solutions. Some aspects of the plan may require substantial revision or a completely different approach to be workable. A central problem with the plan is that it tries to straddle the line between an income tax and a consumption tax, inconsistently taking elements of both. In some cases, this generates inconsistent taxation of different types of investments and unnecessary complexity. In other cases, the mix is entirely unworkable. Solving these problems by shifting to a pure consumption tax, however, would put the United States in new territory: no developed country has tried to have a pure consumption base for its tax system.

Although there is a strong impetus to pass a tax reform plan quickly, finding reasonable and durable solutions to many of the issues will take time. This is particularly so because consumption tax approaches to tax issues are very different than income tax approaches, and there is little expertise in the United States on how to approach taxes when the base is consumption. It is easy to make mistakes by relying on an understanding of how income taxes work. For example, deferral is one of the central problems in designing an income tax, but is largely irrelevant in a consumption tax. Income tax concepts like basis, inventory, and capitalization of expenses no longer apply. Legislative drafters, experienced in income tax design, will have to work hard to avoid importing income tax concepts into a consumption tax. Doing so quickly and, possibly, on a partisan basis if tax reform is passed as part of budget reconciliation, will be difficult. Nevertheless, I will conclude that with work, a plan following the basic contours of the Brady plan can be implemented and, if the right choices are made, may, in many areas, be substantially simpler than current law.

\section{DESCRIPTION OF THE PROPOSAL}

The following is a summary of the proposal taken from the June 24, 2016 description of the plan found in the Ways \& Means Committee website. ${ }^{9}$ The description on the website is just a rough outline and has many ambiguities. It is likely that in some places my interpretation is incorrect. Moreover, many elements will be changed as the plan is developed in more detail.

\footnotetext{
${ }^{9}$ Supra note 2.
} 


\section{A. Business Level Tax}

Corporations. The plan makes four key changes to the corporate tax:

- The cost of capital expenditures (other than land) would be immediately deductible instead of recovered over time through depreciation deductions.

- Net interest expense would not be deductible. In effect, interest expense would be treated similarly to dividends, reducing the disparity between debt and equity. Nondeductible interest expense can be carried forward and used against interest income in future years.

- The tax would be territorial, which means that it would apply only to income from domestic activities. Accumulated foreign earnings at the time of the tax, however, would be subject to a one-time tax of $8.75 \%$ for cash holdings and $3.5 \%$ for other assets, without regard to whether they are repatriated. This transition tax would be payable over an eight-year period.

- The tax would be destination-based, which means that sales in foreign countries would not be taxed and imports from foreign countries would not be deductible (or give rise to basis).

The plan would also eliminate most special deductions and credits currently allowed to corporations such as the domestic production deduction. It would, however, retain a version of the R\&D credit. The tax on this base would be $20 \%$.

The plan describes these changes as moving the system towards what is called a cash-flow consumption tax. In a cash-flow consumption tax, firms deduct outflows and include inflows rather than using the usual income tax concepts such as basis, realization, capitalization, and the like. As will be discussed, it is a tax on consumption rather than income.

There are, however, a number of statements in the plan that are inconsistent with cash-flow taxation. In particular, the plan says that it will keep inventory accounting. Inventory accounting would not be necessary in a cash-flow system because the cost of assets is deducted when purchased or created. The plan also does not allow a deduction for purchases of land, so that expenditures on land are treated differently than other expenditures. In a cash-flow system, all (nonfinancial) expenditures would be deductible.

Cash-flow consumption taxes are also usually what is called Rbased, which means that they ignore financial flows such as borrowing and lending. They tax only real flows, hence the R. An alternative is 
what is called $\mathrm{R}+\mathrm{F}$ based, which means that the system taxes all real and all financial flows (other than with respect to stock) on a cash-flow basis. ${ }^{10}$ The Brady plan, as described, is consistent with neither of these approaches. In particular, it taxes net interest income but denies a deduction for net interest expense. In an R-based system, interest income would not be taxed. In an $\mathrm{R}+\mathrm{F}$ system, interest expense (and the principal of loans) would be deductible. Moreover, the plan is silent on other financial flows, such as gains and losses from the sale of securities and derivative instruments.

It is not clear whether these deviations from an R-based cashflow tax are mistakes or are on purpose. The description of the plan gives no explanation. In Part IV.A., I will discuss the problems these deviations from an R-based cash flow system create.

Pass-through entities. The plan keeps the current law tax rules for pass-through entities. This means that the tax rules for partnerships under subchapter $\mathrm{K}$ and for closely-held corporations under subchapter $\mathrm{S}$ would remain. The tax base ${ }^{11}$ for these entities has the same features as the corporate tax base: immediate deduction for capital expenditures, no deduction for net interest expense, territorial taxation, and destination-based cash flow determination.

Once a pass-through entity computes its tax base and allocates it to its owners, the owners report their amounts on their personal returns. The tax rate for the active earnings of pass-through entities is capped at $25 \%$ which means that the applicable rate is the lesser of the owner's marginal tax rate and $25 \%{ }^{12}$ Because this rate cap applies only to active earnings, passive income of pass-through entities (which is not defined) would presumably be taxed at the owner's marginal tax rate, not capped at $25 \%$.

\section{B. International Tax Rules}

As mentioned, the tax would be destination based, which means that exports would not be taxed and imports would be subject to tax. In practice, what this means is that a U.S. company that sells a

${ }^{10}$ The $\mathrm{R}+\mathrm{F}$ base was first described by the Meade Commission. The Structure and Reform of Direct Taxation, INST. FOR FISCAL STUDIES (1978).

${ }^{11}$ Throughout, rather than using "income" I use "tax base". If the reform shifts the tax system to a consumption tax, the tax base would not be income, and it is misleading to say that a business computes its income on a cash-flow basis. Instead, I will say that a firm computes its tax base, or where grammatically simpler, its earnings.

${ }^{12}$ An alternative interpretation of the language in the plan, suggested to me by Steve Shay, is that pass-through income is taxed at a flat $25 \%$ rate. It is not clear which interpretation is correct. 
good in a foreign country would not include the proceeds in its tax base. Conversely, a U.S. company that imports a good would not be able to deduct the cost of the good so that when the good is sold in the United States, its full value is included in its tax base and taxed (as opposed to just the value added in the United States).

The plan is also territorial, which means that U.S. corporations are not taxed on income earned in other countries. Because sales in other countries and active income earned in other countries are not taxed, most tax rules governing outbound transactions would be repealed. The plan indicates that the foreign personal holding company rules would remain.

The plan does not mention which rules governing inbound investments would remain. For example, the plan does not say whether it would retain the withholding rules for dividend payments made to foreigners or the branch profits rules. Similarly, the plan does not say which source rules would be retained or how they would be modified.

\section{Other Entities}

The plan does not say how other entities, such as banks, regulated investment companies, insurance companies, real estate investment trusts, REMICs, and other entities will be taxed. The plan does not mention tax-exempt entities, and I assume that means no changes would be made to their treatment. The plan does not mention the Unrelated Business Income Tax, although this would likely be reformed to match the new business tax rules.

\section{Individual Level Taxation}

To a great extent, the taxation of individuals under the plan is similar to their taxation under current law. The basic intent seems to be to simplify the ornate structure of taxation that has built up over the years.

In particular, the plan would tax wage or labor income at progressive rates, with three brackets, $12 \%, 25 \%$, and $33 \%$. It would have a large standard deduction, in the range of $\$ 24,000$ for a married couple, and a combined child credit and personal exemption of $\$ 1,500$. The AMT would be repealed. The plan does not mention payroll taxes, which, I assume, remain as is.

Many of the features of the tax system for individuals found in current law would remain roughly as is, with unspecified simplifications. For example, the plan says that it will preserve "a" mortgage interest deduction, and that the Committee on Ways and Means will evaluate options to make it more effective and efficient. 
Similar language is used for the deduction for charitable donations, the exclusion for employer provided health care, the various education tax benefits, and the various retirement savings provisions found in current law. With the exception of the mortgage interest deduction and the deduction for charitable donations, all itemized deductions would be repealed (which means that the plan would repeal the state and local tax deduction). The Earned Income Tax Credit would remain. Presumably, the rules defining the scope of taxable compensation, such as the fringe benefit rules, would remain.

The most important difference from current law for individuals is that all income from capital, including interest, dividends, and capital gains would be taxed at half the rate applicable to labor income. This change would reduce the highest tax rate on dividends and capitals from $25 \%$ (the $20 \%$ statutory rate plus the $3.8 \%$ surtax on net investment income plus the Pease surtax) under current law to $16.5 \%$ and the highest tax rate on interest income from $44.6 \%$ to $16.5 \%$ (a $63 \%$ cut). While business taxes are territorial, I assume that the individual capital income tax is not. That is, I assume that dividends, interest, and capital gains, regardless of the source, would be taxed.

\section{E. Estate and Gift Taxation}

The plan would repeal the estate tax and the generation skipping taxes. It is silent on the gift tax, which I take to mean that the gift tax would be retained. ${ }^{13}$ It does not mention whether it would retain stepped-up basis at death.

\section{F. Revenue and Distribution}

The description of the plan does not include a revenue estimate or distributional tables. It is not clear whether estimates were used to arrive at the tax rates stated in the plan. If not, the stated tax rates may have to change, possibly significantly, to reach appropriate targets. In particular, the Tax Policy Center estimates that the plan lowers tax receipts by about $\$ 3.1$ trillion over ten years on a static basis and $\$ 3$ trillion on a dynamic basis. ${ }^{14}$ The Tax Foundation's static estimate is that the plan would lose $\$ 2.4$ trillion over ten years, which is roughly

${ }^{13}$ The Tax Policy Center analysis made the opposite assumption, that the gift tax will be repealed. See Burman et al., supra note 4 at 264.

${ }^{14}$ Burman et al., supra note 4 , at 273 also estimate that the plan would be highly regressive. In its first year of operation (which they assume is 2017), the top 0.1 percent of taxpayers would receive a tax cut of about 16.9 percent of their aftertax income. Households in the middle fifth of the income distribution would receive cuts of about 0.5 percent of their after-tax income. The poorest fifth would have tax cuts of 0.4 percent. 
in the same ballpark, although their dynamic estimate is that the plan would lose only $\$ 191$ billion, which is effectively revenue neutral. ${ }^{15}$

These estimates need to be taken as provisional because so many of the details of the plan remain unspecified. For example, the plan does not state how existing basis will be treated once the corporate tax shifts to an expensing system. Many of these details will have large effects on tax revenues and also on the distribution of the tax burden.

The size of the tax cut and the distributional effects of the plan will likely be headline items in the press coverage of the plan. The focus here, however, is on the structure of the proposed tax system. There are two reasons for this focus. First, there has been little attention to structural issues, and these issues will have first order effects on the operation of the plan and its economic effects. Second, the revenue and distributional impacts, while contentious, are, to a great extent, relatively easy issues to resolve by choosing appropriate marginal rates. That is, there may be deep philosophical issues about the right degree of progressivity of the tax system and the right overall level of taxation, but any given resolution of those issues is relatively easy to implement through the choice of the rates. The structural issues may be much more difficult to resolve.

III. HOW DID WE GET HERE?

To understand the overall structure of the Brady plan, we need to understand the proposals for consumption taxation that have been made over the last 40 years. I offer a summary here. More detail can be found in numerous sources. ${ }^{16}$

\section{A. Consumption Tax Basics}

${ }^{15}$ Kyle Pomerleau, Details and Analysis of the 2016 House Republican Tax Reform Plan, TAX FouND. (July 5, 2016), http://taxfoundation.org/details-andanalysis-2016-house-republican-tax-reform-plan/ [perma.cc/88UK-5CGK].

${ }^{16}$ Much of the original work was done by David Bradford, including his works cited in note 7, David F. Bradford, Transition to and Tax-Rate Flexibility in a Cash-Flow-Type Tax, 12 TAX POLICY ECON. 151-172 (1998), DAVID BRADFORD, THE X TAX IN THE WORLD ECONOMY (2004), and U.S. DEPARTMENT OF THE TREASURY, BLUEPRINTS FOR BASIC TAX REFORM (1977), which was primarily authored by Bradford. Other work on implementation of consumption taxes includes William D. Andrews, A Consumption-Type or Cash Flow Personal Income Tax, 87 HARV. L. REV. 1113 (1974); Michael J. Graetz, Implementing a Progressive Consumption Tax, 92 HARV. L. REV. 1575-1661 (1979); Weisbach, Ironing Out the Flat Tax, supra note 5; Weisbach, Does the X-Tax Mark the Spot?, supra note 5; RoBERT CARROLl AND AlAN D. Viard, PROGRESSIVE CONSUMPTION TAXATION: THE X-TAX REVISITED (2012). 
Individuals can do two things with their income: they can use it for consumption or they can save it. Robert Haig and Henry Simons proposed defining income this way, according to its uses. In their formulation, an individual's income in a given period is his consumption plus his change in net worth or savings.

Using this same identity, consumption is income minus changes in savings. This means that we can measure consumption by measuring income and allowing a deduction for savings (and an inclusion for withdrawals from savings).

An income tax with a deduction for savings (that is, a consumption tax) is simply a tax on cash flows. ${ }^{17}$ Taxpayers have income in a given year, say as salary or gains from investments. This income is an inflow. They subtract from this any amounts they save their outflows. They pay tax on what is left, which is their consumption.

What makes this system so attractive from an administrative and compliance standpoint is that it does not need to use income tax accounting concepts such as realization, basis, depreciation, accrual, inventories, capitalization, and the like. To tax consumption, we just need to measure inflows less outflows. Switching to a cash-flow system, therefore, potentially allows substantial simplification of the tax rules.

A cash-flow system allows an immediate deduction for savings. Students of the tax law will remember that an immediate deduction of an expenditure is, with an exception discussed below, the equivalent of not taxing the return on the expenditure. To illustrate, suppose you purchase a share of stock or a machine for $\$ 100$ and it produces a return of $\$ 110$ in one year, for a $10 \%$ rate of return. An income tax would give you basis of $\$ 100$, an amount realized of $\$ 110$, and gain of $\$ 10$. At a tax rate of $20 \%$, you would owe $\$ 2$.

A cash-flow system would allow an immediate deduction of the $\$ 100$ purchase, saving you $\$ 20$ in taxes. ${ }^{18}$ You do not have any basis in the asset (because you deducted its cost), so when you get the

${ }^{17}$ This observation was first made by NichOLAS KALDOR, EXPENDITURE TAX (1955). Andrews, supra note 16, expanded on and developed the idea.

${ }^{18}$ The deduction either reduces taxes you would otherwise owe, or if you do not otherwise owe $\$ 20$, would, in a pure cash-flow tax, be refundable. The Brady plan does not refund losses. Instead, it allows unlimited carry forwards with interest, which in economic terms is roughly the same thing. In the example, you would carryforward the $\$ 100$ loss, increasing it by $\$ 10$, to have a $\$ 110$ loss which could be used against the $\$ 110$ of income. 
$\$ 110$ the next year, you have $\$ 110$ of gain, and owe $\$ 22$ in taxes. But note that the $\$ 22$ you owe next year is just the future value of the $\$ 20$ in taxes that you saved this year (at the 10\% market rate of return). In present value terms, you owe no tax. In fact, if you wanted, you could invest the \$20 tax savings at the 10\% market rate of return and have $\$ 22$ next year, so that you will have exactly enough to pay the tax. ${ }^{19}$ In this case, the tax has no effect on you at all: you get the refund, put it in the bank, and take it out of the bank at a future date to pay the tax. Your investment is unaffected. Therefore, in a cash-flow system, the investment bears no effective tax. As the Brady plan puts it, the effective marginal tax rate on new investment in a cash-flow system is zero.

Note that this is true regardless of the tax rate. If the rate were, say, $70 \%$, the same analysis would hold. The deduction for the initial investment of $\$ 100$ would be worth $\$ 70$ and the tax on the return of $\$ 110$ would be $\$ 77$. The present value of these flows is $\$ 0$. Because the effective marginal tax rate on new investment is zero, the nominal rate does not matter for new investment.

An exception to this conclusion is if the investment produces higher returns than are otherwise available in the market (adjusting for risk). ${ }^{20}$ These returns are variously called "inframarginal returns," "rents," or "economic profits." To illustrate, suppose that the market rate of return is $10 \%$ but the investment has a yield of $20 \%$, so that in one year you get back $\$ 120$ instead of $\$ 110$. In the year of the investment, you save \$20 in tax. The next year, you have \$120 in incoming cash flows, so you owe $\$ 24$ in tax. The amount you owe, $\$ 24$, is $\$ 2$ more than in the $\$ 22$ owed in the prior case when you only received the market rate of return. The additional $\$ 2$ is the $20 \%$ tax on the $\$ 10$ you earned that is above the normal market rate of return. If you put your tax refund of $\$ 20$ in the bank, you would have only $\$ 22$ next year. You would have to dig into your own pocket to find the additional $\$ 2$ that you owe.

This analysis allows us to describe a consumption tax more precisely (which will end up being important in thinking about the structure of the Brady plan). There are two sources of income: income from labor and income from saving and investing. A consumption tax

${ }^{19}$ The investment of the $\$ 20$ would also be deductible, producing $\$ 4$ of tax savings, which you could also invest. Continuing this process, you would eventually be able to invest $\$ 25$ in tax savings and owe $\$ 27.50$, the future value of $\$ 25$, in taxes.

${ }^{20}$ The other key assumption is that tax rates stay the same. The effects of changing tax rates are discussed in Part IV.H. 
is the same as an income tax except that (because of its cash-flow structure) it exempts the normal return from savings, but not economic profits. A consumption tax, therefore, can be thought of as a tax on labor income and economic profits.

There is also, potentially, a third component of a consumption tax, which relates to transition effects. Depending on how the transition is managed, a consumption tax might also fall on existing capital. If we think about sources of consumption in the future, one major source is liquidating existing investments, and using the cash to purchase consumption. For example, if you were retiring today, all or almost all of your future consumption would come from your existing investments, not from labor income or economic profits.

The Brady plan is silent on transition, so I will defer discussion of this issue (including a discussion of why the transition effect can occur). Because of the large existing base of capital, a tax on existing capital will substantially affect the overall operation of the tax, so it will be important to resolve the issue.

B. The Cash-Flow or Subtraction-Method VAT

An alternative way to tax consumption is to tax consumption purchases at the point of sale, a system known as a retail sales tax. ${ }^{21}$ If a retailer sells a widget to a consumer for $\$ 100$, the consumer has $\$ 100$ of consumption. We can simply have the retailer remit $\$ 20$ of taxes to the government, thereby imposing a tax on the consumption of the widget. And although it would not be remotely obvious from thinking about a retail sales tax, since it is a tax on consumption just like a cashflow tax is, it too is effectively a tax on labor income and economic profits, plus possibly existing capital depending on the transition rules.

The problem with retail sales taxes is that they are relatively easy to avoid: retailers simply sell goods under the counter for cash, sharing the tax savings with their customers. A VAT can be thought of as a retail sales tax designed to prevent fraud and to reduce the consequences of any fraud that remains. The way VATs do this is by collecting tax at each level of production.

To illustrate how a VAT works, we must know more about how the widget is produced. Suppose that our widget is produced in two stages. A manufacturer builds the widget using labor. Its labor costs are $\$ 50$. The manufacturer then sells the widget to a retailer for $\$ 70$.

\footnotetext{
${ }^{21}$ Retail sales taxes, used in many states, tend to have narrow bases - for example they often exclude services - but retail sales taxes could, at least in theory, apply to the purchase of all consumption.
} 
The retailer sells it to the customer for $\$ 100$ and in doing so, incurs labor costs of $\$ 20$. Table 1 summarizes these numbers.

Table 1

\begin{tabular}{lll}
\hline Assumptions & & \\
\hline & Manufacturer & Retailer \\
Purchase price & $\$ 0$ & $\$ 70$ \\
Labor cost & $\$ 50$ & $\$ 20$ \\
Sales price & $\$ 70$ & $\$ 100$ \\
Profit & $\$ 20$ & $\$ 10$ \\
\hline
\end{tabular}

A subtraction-method VAT is a tax on the cash flow at each stage in production, except there is no deduction for wages and financial flows are ignored. The retailer has a $\$ 100$ inflow and a $\$ 70$ outflow (not counting wages), so the retailer has a VAT base of $\$ 30$. If the rate is $20 \%$, the retailer owes $\$ 6$ in tax.

The manufacturer has a $\$ 70$ inflow and no non-wage, nonfinancial outflows, so it has a VAT base of $\$ 70$ and owes taxes of $\$ 14$. Together, the manufacturer and retailer owe $\$ 20$, which is the same amount that would be owed under a retail sales tax. Therefore, a system that taxes the cash inflows of businesses and allows deductions for purchases of inputs from other businesses (in other words, a cashflow system at the business level) is equivalent to a consumption tax. A VAT that measures cash flows, that is, a system that allows a deduction for purchases and an inclusion for sales, is called a "subtraction method" VAT. Table 2 summarizes the taxes imposed through such a system.

Table 2

\begin{tabular}{lll}
\hline Subtraction Method VAT & & \\
\hline & Manufacturer & Retailer \\
Sales & $\$ 70$ & $\$ 100$ \\
Less purchases & $\$ 0$ & $\$ 70$ \\
Net & $\$ 70$ & $\$ 30$ \\
Tax at $20 \%$ & $\$ 14$ & $\$ 6$ \\
Total tax collected & & $\$ 20$ \\
\hline
\end{tabular}

The key difference between a retail sales tax and a VAT is that if a business does not participate in the system - it refuses to pay taxes 
and does not claim deductions - the only tax that is lost is the tax at that level of production. For example, under a retail sales tax, if the retailer is a tax cheat and does not file tax returns, all $\$ 20$ of taxes are foregone. In a VAT, the government still collects taxes paid at prior levels, in this case $\$ 14$.

Note that the system ignores financial flows. We said nothing about how the retailer or manufacturer financed their businesses, how much stock or debt they had, and so forth. We simply ignored financial flows, which means, among other things that the businesses could not deduct their interest expense. With the exception of the consumption of financial services, discussed below, there is no need to consider financial flows when measuring consumption. Because the system only taxes real flows, not financial flows, it is known as an R-based tax. As we will see, consumption can also be measured by including financial flows through a system known as an R+F-based tax.

European VATs do not work exactly as described in the example. Rather than getting a deduction for the cost of their purchases, purchasers get a credit against tax for any tax paid by the seller, under a system known as a credit invoice VAT. As we know, however, credits and deductions are the same thing using different units. In a $20 \%$ tax, a $\$ 20$ credit is the same as a $\$ 100$ deduction. Both save you $\$ 20$ in taxes. Going back to the example, in a credit invoice VAT, the retailer would have an inflow of $\$ 100$ and owe a tax of $\$ 20$ but would get a credit for the $\$ 14$ of tax paid by the manufacturer, so it would owe $\$ 6$, exactly as in the cash-flow system. The only difference is that instead of deducting $\$ 70$, the retailer gets a credit of $\$ 14$; different language to describe the same thing.

The reason European VATs use the credit invoice system is the invoices: the retailer gets an invoice from the manufacturer stating that the manufacturer paid \$14 in VAT on the widget. The retailer can only claim a credit for the purchase of the widget if it gets the invoice. This generates an incentive for the retailer to demand that the manufacturer pay tax, and it creates a paper trail for audits. It also ensures that the system is what I have called "closed." 22 Purchasers only get deductions or credits when sellers have paid a tax on the sale. Ensuring that the system is closed has important implications both for the scope

${ }^{22}$ Weisbach, Ironing Out the Flat Tax, supra note 5. 
of the tax base and for enforcement. ${ }^{23}$ Subtraction method VATs could require invoices, but proposals for subtraction method VATs almost never do.

\section{Destination v. Origin Basis: The Treatment of Cross- border Purchases and Sales}

VATs around the world are, without exception, destinationbased. In a destination-based system, exports are exempt from tax and imports are taxed.

In our example, under a destination-based system, if the retailer sells the widget in Canada, it would not have to include the $\$ 100$ cash inflow. Because it does not count its $\$ 100$ inflow, it has a net outflow for tax purposes of $\$ 70$, so it would get a $\$ 14$ rebate from the government. This rebate is known as a border adjustment and destination-based taxes are sometimes called "border adjustable" taxes. The border adjustment offsets prior taxes so that there is no net tax on the sale in Canada. This means that goods sold in foreign countries are exempt from U.S. tax.

In the other direction, goods produced in foreign countries and sold in the United States are subject to tax. For example, if the retailer bought the good from a Canadian manufacturer, it would not get a deduction for its $\$ 70$ purchase price. When it sells the widget in the United States for $\$ 100$, the retailer is taxed on the full amount, so it would owe $\$ 20$ in tax. This means that the tax is the same on imported goods as goods produced in the United States. In both cases, the tax is $\$ 20$ on a good that ultimately sells for $\$ 100$.

A destination-based tax can be thought of as a tax on domestic consumption regardless of where goods are produced. If a good is produced domestically, there is a tax on the good only if it consumed domestically - border adjustments remove the tax if the good is exported. If a good is produced abroad, it is taxed if it is consumed domestically because border adjustments impose a tax when it is imported.

The alternative to a destination-based system is an origin-based system. In this system, domestic producers owe tax on the sale of their goods regardless of where the sale occurs. In the example, there would be $\$ 20$ of tax on the manufacture and sale of the widget even if it is

${ }^{23}$ For example, in a closed system, purchases from tax-exempts or other non-taxpayers are not deductible while in a system that is not closed - what I termed "open" - these purchases are deductible. The tax base is different in the two cases because in a closed system, value added by non-taxpayers is eventually taxed (unless provided directly to individuals for consumption) while in an open system it is not. The Brady plan is an open system. 
sold in Canada. Goods produced abroad would not be taxed when sold here. This would mean that the retailer in our example would be able to deduct the $\$ 70$ costs of the widget that it imports for sale here and pay tax only on the $\$ 30$ value added in the United States.

An origin-based tax can be thought of as a tax on domestic production regardless of where the goods are sold. Goods produced domestically bear a tax even if sold abroad. Goods produced abroad do not bear a tax even if consumed domestically.

A common reaction to these systems (repeated in the Brady plan) is that the destination-based system is better for domestic producers. Under a destination-based system, both U.S. and foreign producers face the same tax when they sell goods in the United States. For sales abroad, the tax is removed allowing U.S. producers to compete with foreign producers.

With an origin-based tax, goods sold by U.S. producers in a foreign country still bear a U.S. tax. Foreign producers selling in their own country do not face a U.S. tax, seemingly giving them an advantage over U.S. producers. Similarly, foreign producers selling in the United States would not face a U.S. tax but competing U.S. producers would, again seeming to give foreign producers an advantage.

There is, however, a long line of literature showing that this initial reaction is incorrect. Rather than repeat the arguments in the literature, I refer readers to the many sources that explain it in detail. ${ }^{24}$ One intuition for the result is that in present value terms, domestic production (the base of an origin-based tax) and domestic consumption (the base of a destination-based tax) have to be equal. You can trade production today for consumption in the future (generating a trade surplus) or vice versa (generating a trade deficit) but in present value terms, trade has to balance. You can only consume what you have produced.

${ }^{24}$ The literature on this issue is extensive, including, for example, Martin S. Feldstein \& Paul R. Krugman, International trade effects of value-added taxation, in TAXATION IN THE GLOBAL ECONOMY 263-282 (1990). For a recent accessible discussion, see Alan J. Auerbach \& Douglas HoltZ-EAKIn, THE Role OF Border AdJUSTMENTS IN INTERNATIONAL TAXATION, AMERICAN ACTION FORUM RESEARCH PAPER (2016). Note that the comparison in the text is between destination-based and origin-based consumption taxes. The U.S. currently has a source-based income tax. Eliminating the current source-based tax, as proposed in the Brady plan, would very likely affect location decisions. 
Rather than through trade balance, the equivalence is usually explained in terms of price effects, which, with floating currencies, can be achieved by a change in the relative price of the currency. A destination-based tax increases demand abroad for U.S. goods, strengthening the dollar, which then offsets any apparent advantage for U.S. producers. ${ }^{25}$ With a $20 \%$ tax rate, the dollar would increase by $25 \%$ so that an imported good that previously cost $\$ 100$ now costs $\$ 80$.

${ }^{25}$ Michael Graetz gives the following illustration, taken from Al Warren:

Suppose that the U.S. has an origin-based VAT of 10 percent with no border adjustments, and that a U.S. consumer product which costs $\$ 100$ to produce will sell for $\$ 110$, including the tax, whether sold in the U.S. or for export. Assume that a comparable product is produced in country $\mathrm{Z}$ and sells for $110 \mathrm{Z}$ in the local zed currency. Assume further that the exchange rate between the U.S. dollar and the $\mathrm{Z}$ zed is $\$ 1=1 \mathrm{Z}$. Finally, for simplicity assume that there are no transportation costs for shipping the products.

Under these conditions, consumers in the U.S. and $\mathrm{Z}$ will choose between the two products on the assumption that they will sell for identical prices. Consumers in $\mathrm{Z}$ have the choice of buying the $\mathrm{Z}$ product for $110 \mathrm{Z}$ or buying the U.S. product for $\$ 110$, which will require 110Z. Similarly, the U.S. consumers can buy either product for $\$ 110$. A U.S. producer has the choice of selling in the U.S. market for $\$ 110$ or exporting for $110 Z$, which will yield $\$ 110$. In either case, the U.S. product will retain $\$ 100$ after payment of taxes.

What will happen if the U.S. replaces its origin based VAT with a destination-based VAT that exempts exports and taxes imports? Initially, the Z product appears more expensive to U.S. consumers than the U.S. product because the $\mathrm{Z}$ product will sell for $\$ 121$ (the old price of $\$ 110$ plus the new 10 percent tax) whereas the U.S. will still sell for $\$ 110$. Similarly, the U.S. product now looks less expensive than the $\mathrm{Z}$ product to country $\mathrm{Z}$ consumers, because the tax rebate means that the U.S. product can now be exported from the U.S. for $\$ 100$. The U.S. producer might therefore think it has an advantage in $\mathrm{Z}$, where the comparable local product continues to sell for $110 \mathrm{Z}$. Hence it is often argued that a destinationbased VAT would stimulate exports and that an origin-based VAT would not.

Now consider what happens when the U.S. and Z consumers start to switch from $Z$ products to U.S. products because the latter appear less expensive. That switch would mean that there would be less demand for the $Z$ currency by U.S. nationals (who are reducing their imports of the $\mathrm{Z}$ products) and more demand for the U.S. currency by $Z$ nationals (who are increasing their imports of the U.S. product). Given this change in demand, the value of the dollar will rise relative to the zed until there is no longer any advantage to switching from $\mathrm{Z}$ products to U.S. products, given consumer's preferences relating to matters other than price, which preferences are independent of the tax law. In this simple example, the value of the dollar would rise until \$1 could be exchanged for 1.1Z.

U.S. consumers would then have the choice between buying the U.S. product for $\$ 110$ (including the tax) or the $\mathrm{Z}$ product for $\$ 100$ (which would be exchanged for 110Z) plus the 10 percent tax on imports, for a total of $\$ 110$. Z consumers would have the choice between buying the $Z$ product for $110 Z$ or the U.S. product for $\$ 100$, which would require 110Z. Similarly, U.S. producers would be indifferent between selling in $\mathrm{Z}$ or domestically. 
Currency effects, however, do not offset all of the differences between origin and destination-based taxes. In particular, to the extent that there are inframarginal returns, the two are not equal. Again, I will leave the details to others, but destination-based systems tax any economic profits U.S. consumers earn from investments abroad (even if made through a domestic multinational corporation) and exempt economic profits that foreign consumers earn in the United States. Origin-based taxes are the reverse: they tax U.S. economic profits of foreign producers and exempt foreign economic profits of U.S. producers. $^{26}$

The equivalence between destination and origin-based taxes (other than for economic profits) is an article of faith for economists, and, as far as I can tell, believed by nobody else. The Brady plan, for example, argues that border adjustments will help U.S. businesses compete with foreign businesses. Even if you believe that the destination and origin-based systems have the same economic effects, however, there may be good reasons to prefer one over the other because they have different administrative and compliance effects. In

Taking into account the change in exchange rates brought about by the change in the relative prices of the U.S. and Z products due to the introduction of border adjustments, the destination-based VAT has no advantage over the originbased VAT in terms of stimulating exports. One of the U.S. products exchanges for one of the $\mathrm{Z}$ products in both the U.S. and country $\mathrm{Z}$ under both taxes, and the U.S. producer earns the same amount from a sale at home and a sale abroad under either tax.

Michael Graetz, International Aspects of Fundamental Tax Restructuring: Practice or Principle?, 51 U. MiAMI L. REV. 1093-1247 (1997).

${ }^{26}$ One intuition for this result is to think of a destination-based system as a cash-flow system for outbound investment. The border adjustments acts like a deduction for flows out of the country and a tax for flows into the country. A cash flow tax will impose a present value tax for inframarginal returns received abroad because the present value of the tax on the inflow will exceed the tax rebate on the outflow. Origin-based taxes do not give the deduction on outflows and do not tax inflows so they do not tax inframarginal returns by U.S. consumers. The argument is reversed for inbound investment.

Although this paper focuses on implementation issues rather than revenue, distributional, or efficiency effects, it is worth noting that the two systems do not raise the same revenue if a nation imposes a consumption tax when it is either a net creditor or a net debtor. To the extent that a nation is a net debtor, it expects to export more in the future than it imports, which means that in present value terms, the origin base is larger than the destination base. In budgetary terms, which only look at a 10-year window and which do not use present values, however, a destination base may raise more money than an origin base, depending on the trade deficit or surplus during the budget window. For example, if the United States expects to run a trade deficit during the budget window, a destination-based tax will raise more revenue in that window. 
particular, many prefer a destination-based system because it eliminates the problem of transfer pricing.

To illustrate why destination-based systems do not face transfer pricing problems, consider again our running example of a manufacturer and retailer but suppose, now, that the retailer is a foreign entity (so it does not bear U.S. tax). Under a destination-based tax, any foreign sales are excluded. Because the retailer is foreign, when the manufacturer sells to the retailer, the sale is not taxed. The price, therefore, has no effect on the manufacturer's taxes. The manufacturer pays the same tax on the sale ( $\$ 0$ ) if the price is $\$ 0$, the price is $\$ 70$, or is any other value.

Under an origin-based tax, the manufacturer pays tax on its sale to the foreign retailer because sales abroad are taxed. The price, therefore, determines how much tax the manufacturer pays. It matters whether the price is $\$ 0$ or the price is $\$ 70$. If the manufacturer and retailer are not related, we can rely on the $\$ 70$ price to be the true price. If the manufacturer and retailer are under common control, however, there may be an incentive to understate the price of the good when sold to the retailer to reduce U.S. taxation. If the price is $\$ 70$, the manufacturer has a VAT base of $\$ 70$ while if the price is $\$ 0$, its base is $\$ 0$. (The foreign retailer would have a correspondingly higher VAT base but it is not taxed by the United States because it is foreign.)

Therefore, origin-based systems require transfer pricing rules while destination-based systems do not. Eliminating transfer pricing disputes and the accompanying the massive enforcement resources is a major advantage of a destination-based tax, and the core reason why many recent proposals have been destination-based.

D. The Flat Tax and the X-tax

Destination-based VATs are used through-out the developed world. We know how they work and how to implement them. If the United States were to adopt a destination-based VAT, there would be few new implementation problems. We could simply pick from the best practices used in other countries.

The problem with VATs, however, is that they are regressive. There are a number of different ways we can measure the progressivity of a tax system. The most common way is taxes paid relative to income: we look at the tax paid as a fraction of income at each level of income. VATs are regressive when measured this way because the rich consume a lower percentage of their income than the middle-class or the poor so that tax as a percentage of income goes down as income goes up. More generally, because VATs are imposed at the business level, they cannot easily be sensitive to the circumstances of individual 
taxpayers, which means that there is no easy way to make a VAT progressive.

The so-called Flat Tax and the X-tax modify the VAT to reduce, and possibly eliminate, this problem. These systems allow business to deduct wages and salaries, and tax wages and salaries to individuals. Because individuals are taxed on their labor income, the tax rate can be based on each individual's or family's level of income (and other attributes such as mortgage and education payments, retirement savings, and charitable donations). They allow personalization of the tax and allow the tax to be progressive. (The Flat Tax, for reasons that are unclear other than to have a rhyming name, would limit the number of tax brackets to two. The X-tax allows the number of tax brackets to be whatever number is needed. Because it is the more general of the two, I will below refer to this system as the X-tax.)

Recall that a consumption tax is a tax on labor earnings and economic profits (and as discussed in Part IV.H., possibly existing capital on transition). If labor earnings under the X-tax are taxed at the individual level, the business tax is a tax only on economic profits and possibly existing capital on transition. That is, we can think of the $\mathrm{X}$-tax as an individual-level wage tax and a business-level tax on economic profits and, possibly existing capital.

The usual structure of X-tax proposals is to set the businesslevel tax rate to be the same as the highest wage tax rate (which is not what the Brady plan does). For example, if the individual wage tax rates were $12 \%, 25 \%$, and $33 \%$, as in the Brady plan, the business tax rate would be set at $33 \%$. The reason is that this eliminates the incentive for high wage earners to take their labor earnings out of the business as profits rather than salary.

To illustrate, consider the retailer in our running example and suppose that the owner is the only employee. The retailer has $\$ 30$ of total proceeds and the owner/worker's fair wages are $\$ 20$. If both the retailer and the owner/worker are taxed at $20 \%$, it does not matter whether the earnings are paid as salary or not. Either way, there is a $20 \%$ tax on $\$ 30$. If, however, the tax rate on wages and salaries was $33 \%$, any amounts paid as salary would face this higher rate while amounts treated as business profits would face only a $20 \%$ rate. There would be an incentive to avoid paying salaries, and directing the funds to workers in other ways, such as through dividends on shares that they own. 


\section{E. Destination-based X-tax}

The original proposal for the X-tax was origin-based. The reason seems to be that the shift of the wage portion of the base from the business level to the individual level changes how the WTO classifies the tax and, therefore, the legality of using a border adjustment. As will be discussed below, under WTO law, it may be illegal to have border adjustments in an X-tax for reasons relating to how the tax is classified. WTO law only allows border adjustments for "indirect" taxes, which are taxes on businesses. Because the X-tax imposes the wage portion of the tax directly on individuals, it may be classified as "direct" tax, and, therefore, may not be border adjusted under the WTO. Given that destination and origin-based taxes have the same effect on new investment, WTO rules might seem to have no economic effect, requiring one approach and disallowing another, both of which end up in the same place. Therefore, given possible WTO problems, it seemed to make sense to make the X-tax origin-based.

As noted, however, origin-based taxes have transfer pricing problems not faced by destination-based taxes. ${ }^{27}$ Destination based systems will, as a result, be easier to administer. Moreover, as will be shown below, the distinction made by the WTO is non-economic. The $\mathrm{X}$-tax base is the same as the VAT base, so it seems ridiculous to allow border adjustments only for a VAT. And many countries have VATs combined with wage subsidies, so the progressive portion of the wage tax that we find in an X-tax but not a VAT should not change the analysis. Why should the United States be forced by a treaty designed to promote trade into a tax system that is more difficult to administer and that has no trade advantages merely because it wants to make the tax progressive?

Based on these considerations, some believe that the WTO would not in fact hold that imposing border adjustments in an X-tax is illegal. While this may be wishful thinking - legal systems rarely feel a compulsion to follow economic logic - many believe that if the United States were to adopt a cash-flow system, it should be on a destination basis because of the substantial administrative advantages of using a destination base rather than an origin base.

Since the early 2000's, a number of proposals have followed this logic. For example, the Bush tax reform commission studied a

${ }^{27}$ For additional administrative problems raised by the Flat Tax, see Weisbach, Ironing Out the Flat Tax, supra note 5. 
destination-based X-tax. ${ }^{28}$ Although they ultimately did not recommend this system - they favored a system much closer to the Brady plan - they included an extensive discussion of a destinationbased X-tax, showing that it could be revenue and distributionally neutral. Moreover, they ultimately recommended a destination-based system very close to the Brady plan. Similarly a very large study of tax reform in the U.K., known as the Mirrlees Review carefully studied a destination-based X-tax, and the chapter on the design of corporate taxation recommended this system (although the Review as a whole recommended an origin-based system known as an ACE, which has effects but operates differently than the X-tax). ${ }^{29}$

\section{F. The Growth and Investment Tax Plan}

The last step toward the Brady plan is the proposal put forth by the Bush Tax Reform Commission called the Growth and Investment Tax Plan. ${ }^{30}$ This plan is a destination-based X-tax with the addition of a flat $15 \%$ tax rate on interest, dividends, and capital gains at the individual level. ${ }^{31}$

${ }^{28}$ The PRESIDENT's AdVISORY PANEL On FEDERAL TAX REFORM, supra note 3. The first proposal for this system seems to be STEPHEN ROY BOND \& Michael DevereuX, Cash Flow TAXes in AN Open ECONOMY (2002), http://econpapers.repec.org/paper/cprceprdp/3401.htm (last visited Dec 22, 2016). Note that the terminology can get confusing because different taxes are often given the same label. In particular, many different systems are called a "destinationbased cash-flow tax." This description could include a cash-flow VAT (i.e., with no deduction for wages or salaries, ignoring cash flows on financial instruments), an $\mathrm{X}$-tax (i.e., a cash-flow VAT with a deduction for wages and salaries) and what I will call an $\mathrm{R}+\mathrm{F}$ cash flow tax.

${ }^{29}$ Alan J. Auerbach, Michael P. Devereux \& Helen Simpson, Taxing Corporate Income, in MIRRLEES REVIEW, REFORMING THE TAX SYSTEM FOR THE 21st Century (2008); James MirrleEs et AL., TAX By Design (2011). Other studies include Michael P. Devereux \& Peter Birch Sørensen, The Corporate Income Tax: International Trends and Options for Fundamental Reform, EUR. COMMISSION, http://ec.europa.eu/economy_finance/publications/pages/publication530_en.pdf [perma.cc/WSG7-JJ74]; Michael Devereux, Issues in the Design of Taxes on Corporate Profit, 65 NATL. TAX J. 709-30 (2012); Michael Devereux, Rita De La Feria et al., Designing and Implementing a Destination-Based Corporate Tax, (Oxford U. Ctr. for Bus. Tax'n, Working Paper No. 14/07, 2014); ALAN J. Auerbach, A Modern Corporate TAX (2010); Alan J. Auerbach \& Michael P. Devereux, Consumption and Cash-flow Taxes in an International Setting (NBER Working Paper No. 19579, 2013).

30 THE PRESIDENT'S ADVISORY PANEL ON FEDERAL TAX REFORM, supra note 3 .

${ }^{31}$ As noted, the plan also includes a benefit for mortgage interest and the purchase of health care, retirement savings provisions, and a deduction for charitable donations. None of these are in the basic versions of the X-tax. 
Although the reasons for this addition to the destination-based $\mathrm{X}$-tax are not made explicit, it seems that the panel members were concerned about appearances. They showed in their study of the Xtax that, properly structured, the X-tax can be revenue and distributionally neutral. Nevertheless, even if it is distributionally neutral, it would still allow the very wealthy to pay few, if any, explicit taxes to the government. Someone who lived purely off an inheritance would receive no wage income and, therefore, would not have to remit any taxes. While such a person would bear taxes because taxes would be embedded in the price of goods that he purchased and because he may bear a large transition tax, many might view this result as unseemly, particularly in light of concerns about the growth of inequality.

As we will see when considering the implementation of the Brady plan, it will be difficult to make the combination of an X-tax and a flat rate tax on capital at the individual level work. A tax on capital income has to tax the current return to investments. Current law allows some deferral because it waits to impose tax until income has been realized, but it also has a large number of provisions designed to limit deferral.

One of the most important anti-deferral mechanisms in current law is the corporate income tax. If an individual buys stock, he is not taxed until dividends are paid or he sells the stock, creating the potential for deferral. The corporate income tax, however, taxes the current returns to the investment, thereby reducing or eliminating the deferral. If businesses are taxed on a cash-flow basis, they allow deferral by design: because businesses deduct the cost of investments, the returns to investment are not taxed. Keeping money in a business, therefore, gives indefinite deferral. The mere purchase of a share of stock becomes a tax shelter.

\section{G. The Brady Plan}

At this point, the connection to the Brady plan should be clear: the Brady plan is the Growth and Investment Tax Plan with minor modifications (plus, as was mentioned, there are some statements in the Brady plan which are inconsistent with this approach but it is not clear what to make of them). It is time, therefore, to consider the implementation of the Brady plan.

\section{ISSUES AND PROBLEMS WITH THE BRADY PLAN}

The discussion above shows that the Brady plan is based on a long history of thought and research on consumption taxes. Even the purest of these systems has a number of problems, however. Moreover, parts of the Brady plan seem potentially inconsistent with 
these systems, and most if not all of these inconsistencies generate yet additional problems. In the sections that follow, I discuss the eight most central implementation problems that I see in the Brady plan. There are likely many other issues that will also have to be resolved as the legislation moves forward.

\section{A. Design of the Business Tax}

As noted, there are a number of statements in the description of the business-level tax that seem inconsistent with the basic structure of an R-based cash-flow tax. If these statements are inadvertent, they should be fixed. If they are not inadvertent, for the most part they are bad choices and should be reconsidered.

\section{Inconsistent expensing}

There are a number of statements that indicate that the plan would not truly be a cash-flow tax. The two most prominent are (1) the explicit statement that purchases of land would not be expensed and (2) the statement that the LIFO inventory method would be retained.

In a cash-flow system, all non-financial outflows are deductible, including purchases of land and purchases of inventory. It makes no sense to deny deductions for purchase of land and of inventory while allowing a deduction for the purchase of other capital items. If some purchases are taxed on a cash-flow basis and others are taxed on a traditional income tax basis, the effective tax rate on different types of investments will be different. For example, if land is taxed on a traditional income tax basis but machines and buildings are taxed on a cash-flow basis, the effective tax rate on land will be higher than on machines or buildings. This will distort investment patterns and make the tax less efficient.

Moreover, even if there were a reason for introducing this distortion into the system, it would make the system more complex. One of the great virtues of a cash-flow system is its simplicity. Businesses do not need to use complex income tax accounting systems such as LIFO, FIFO, capitalization rules, or accrual concepts like economic performance. Instead, for tax purposes, businesses just deduct cash outlays and include cash inflows. Retaining income tax treatment for some investments means retaining most and possibly all of the income tax accounting rules, foregoing one of the major benefits of a cash-flow system. ${ }^{32}$ Moreover, it requires rules to distinguish investments in land from related investments: taxpayers making a joint

\footnotetext{
${ }^{32}$ Businesses, however, would likely have to continue to use income accounting for book purposes.
} 
purchase of land and improvements have an incentive to allocate the purchase price to the improvements (while sellers would be indifferent).

Although the statements about inventory accounting and the treatment of land are explicit, in other parts of the plan, the corporate tax is described as a cash-flow tax. I cannot think of a reason for keeping land and inventory on a traditional income tax system while putting machines and other capital expenses on a cash-flow system. ${ }^{33}$ Therefore, I take these statements to be mistakes, and they should be fixed.

An alternative reading of the plan is that it is, like current law, a hybrid income-consumption tax system, only shifted more toward the consumption end of the spectrum. The plan might be read as allowing (very) accelerated depreciation and as making an attempt to equalize the treatment of debt and equity. The tax would, for the most part, be an income tax, and the implementation issues with a corporate income tax are well-known. Note, however, that if the plan is to keep the corporate tax as an income tax, it is extremely unlikely that the tax could be destination-based because it would almost surely be inconsistent with the WTO.

Given the various descriptions in the plan as a cash-flow tax and the centrality of border adjustments to the plan, in the remainder of the paper, I will assume that the plan would impose a cash-flow tax on corporations. If instead, the plan merely is an income tax with (very) accelerated depreciation for depreciable investments, most of current law would remain.

\section{Inconsistent treatment of financial instruments}

Separately, there are a number of statements in the plan that indicate that the business-tax portion of the system might not fully ignore financial flows. The draft plan states that net interest expense is not deductible and that any nondeductible interest expense may be carried forward to be used against interest income in a future year. That combined with nothing in the plan indicating that interest and other financial income, such as dividends, gains (and losses) on derivative financial instruments and gains from the sale of stock are exempt creates a strong inference that financial income is taxed. Moreover, it does not seem that financial income is taxed on a cash-

${ }^{33}$ My only guess as to the reason for the apparent treatment of land and inventory is that the drafters of the Brady plan viewed expensing as simply accelerated depreciation so that only purchases that were otherwise depreciable would get expensing. This is not the right way to view expensing in a cash-flow system. Instead, all non-financial cash flows should be deductible. 
flow basis, so it seems that financial income is taxed under the usual income tax rules.

This approach generates a host of problems. Earnings on financial investments would be taxed on an income basis while earnings on physical or intangible investments are taxed on a consumption basis. For example, if you invest $\$ 100$ in a machine that produces $\$ 110$ in one year, the $\$ 10$ return is effectively untaxed, as discussed above. If instead you lend the $\$ 100$ to someone who invests it in the machine and who then pays you $\$ 10$ of interest in one year, the $\$ 10$ is taxed. ${ }^{34}$ The tax base is income when transactions are financed through lending, and the tax base is cash-flow when done directly. There seems to be no reason for disparity, and it may significantly distort how investments are structured.

Denying deductions for net interest expense while taxing net interest income may also generate problems, particularly for firms that have loans between subsidiaries. If internal capital structures are set up so that interest income exceeds interest expense, the firm would have a tax on purely internal flows. For example, suppose a parent firm is capitalized with $\$ 50$ of equity and $\$ 50$ of debt, with the debt instrument paying a $10 \%$ rate of return. The parent capitalizes its subsidiary with, say, $\$ 30$ of equity and $\$ 70$ of debt for good business reasons. If the subsidiary's debt also pays an interest rate of $10 \%$, the parent would have, $\$ 2$ more interest income than interest expense, and would owe tax on this amount. Consolidated filing may reduce this problem somewhat, but not all capital structures allow consolidation of all subsidiaries, so the problem will inevitably remain. Under current law, corporations are allowed dividends received deduction to eliminate this cascading. There is no indication in the plan, however, that there would be a corresponding interest received deduction.

Moreover, denying deductions for interest expense but not expenses and losses on other financial instruments creates administrative complexity and incentives to use other financial instruments rather than debt. For example, lease payments will be deductible but equivalent interest payments will not be, creating incentives to lease rather than to own. Similar problems will arise with respect to swaps, futures and forward contracts which have embedded time-value of money aspects. To some extent current law faces this

${ }^{34}$ Note that the borrower's investment in the machine would be taxed on a cash-flow, so it is effectively untaxed. The borrower would also be denied a deduction for its interest expense. The borrower, in present value terms, therefore, bears no tax and has no deductible expenses. The only net tax on the transaction is the lender's interest income. 
problem, and the response is a host of complex rules designed to classify payments as interest or not. All of these rules and likely many more would be needed under the approach of the Brady plan because the disparity between interest expense and other expenses will be much more significant than under current law.

Finally, the taxation of financial flows on an income tax basis is incredibly complex. The current rules for taxing financial instruments are among the most complex and difficult to understand sets of rules in current law. These rules would have to be retained if financial instruments continue to be taxed on an income-tax basis.

The plan should take an approach to financial flows that is consistent with the consumption tax approach otherwise used in the plan. The standard approach in cash-flow systems is to ignore financial flows. This generates some problems with respect to the taxation of banks and other financial institutions but otherwise works reasonably well in a large number of tax systems used throughout the world. (I defer the discussion of the taxation of financial institutions to Part IV.D.)

\section{Pass-throughs}

The Brady plan would retain the pass-through regimes of current law but tax active income of pass-throughs at a maximum rate of $25 \%$. It is a mistake to retain the pass-through regimes of current law and, with perhaps an exception for small, sole proprietorships, they should be repealed. Instead, all businesses should be taxed the same way. Doing so reduces economic distortions and, simultaneously, would simplify the law.

To see why, compare the taxation under the Brady plan of equivalent investments made, alternatively, through a corporation and through a partnership. Suppose that an individual has $\$ 100$ and can purchase a machine or other asset that costs $\$ 100$ and returns $\$ 110$ in one year. If the individual makes the investment through a corporation, the corporation deducts the $\$ 100$ and includes the $\$ 110$ and pays no present value tax. When the $\$ 110$ is distributed, the owner has a $\$ 10$ dividend and a $\$ 100$ return of capital, ${ }^{35}$ and pays a $\$ 1.65$ tax on the dividend.

Suppose instead that the individual makes the same investment through a partnership. In this case, the cash flows are attributed to the individual via the normal partnership allocation rules. The individual

${ }^{35}$ See Part IV.E. for a discussion of the determination of which portion of a distribution is a dividend and which is a return of capital when corporations are taxed under a cash-flow system. 
deducts and includes the $\$ 100$ expense and $\$ 110$ return at a $25 \%$ rate and bears no present value tax. There is no separate tax on distributions from the partnership.

The net result is that the Brady plan would retain the current law system in which investments in corporations are taxed at a higher rate than identical investments in partnerships and other pass-through entities. It creates an incentive to avoid using the corporate form.

That current law favors partnerships over corporations is a flaw not a feature to be retained. The distortions in investment patterns because of the preference for partnerships over corporations in current law is one of the reasons for the numerous proposals for corporate integration. Among other things, these proposals seek to reduce the distinction between the taxation of partnership investments and corporate investments under our current income tax. ${ }^{36}$ The benefits of reducing the differences in taxation between different business entities would similarly arise under the Brady plan.

Most corporate integration proposals, however, would retain the current system of having separate regimes for partnerships and corporations rather than unifying them in a single business tax regime. Although often not clear exactly why this approach is favored, it seems to be that the partnership regime is thought to be superior in theory but too complex to apply in the large, publicly traded corporation context. The partnership system is superior because it taxes partnership income at the owner's rates while even the most sophisticated corporate integration systems can only approximate this.

With the exception of inframarginal returns, the pass-through system under the Brady plan does not achieve this goal (and even for inframarginal returns, it does not get it exactly right). ${ }^{37}$ Regardless of the investor's marginal tax rate on capital income, partnership flows (other than inframarginal returns) are taxed at a zero rate while other capital income of the owner is taxed at a positive rate. A pass-through regime under the Brady plan fails the basic reason for having a pass through regime.

${ }^{36}$ For example, DEP'T OF THE TREASURY, Integration of the Individual and Corporate Tax Systems, Taxing Business Income Once (1992); and A.L.I., Federal Income Tax Project: Integration of the Individual and Corporate Income Taxes, Reporter's Study of Corporate Tax Integration (1993).

${ }^{37}$ Inframarginal returns of a partnership will be taxed at the lesser of the partner's rate and $25 \%$. For partners whose tax rate is below $25 \%$ (such as taxexempt investors), the partnership regime taxes them at that rate. For partners whose rate is above $25 \%$, the partnership regime does not tax inframarginal returns at their tax rate. 
At the same time that they fail to achieve their only plausible economic goal, pass-through regimes introduce significant complexity. Retaining the pass-through system means retaining the baroque rules of subchapter $\mathrm{K}$, the rules for subchapter $\mathrm{S}$, and adding additional rules to distinguish active earnings of a pass-through (eligible for the $25 \%$ rate) and passive earnings of a pass-through (not eligible for the $25 \%$ rate).

The solution is to repeal the pass-through regimes and to have a business tax regime which applies to all business operations. All business returns would be taxed the same way: normal returns would be taxed at a $0 \%$ rate at the business level and the shareholder's rate when distributed; inframarginal returns would be taxed at a $20 \%$ rate and the shareholder's rate when distributed. There would be no need for the complex partnership tax rules or for other types of separate systems. $^{38}$

The only exception is that it may be desirable to have a simple pass-through system for small, informal businesses such as sole proprietorships. If I am otherwise a wage earner but cut some lawns on the side for extra money, at what point does my lawn mowing business have to be treated as a separate business? A simplified regime for small, closely-held businesses (i.e., one owner or maybe family ownership) would allow small business owners to report earnings on their personal return rather than having to file a separate return.

\section{Losses}

The Brady plan allows net operating losses to be carried forward with interest. If the interest rate used for loss carryforwards is equal to the market rate, this system will have the same present value effect as refundability, but perhaps with a lower potential for fraud.

One problem with this approach is that businesses that consistently have tax losses (but have economic gains) will not be able to use their losses, possibly indefinitely. For example, corporations that produce in the United States but sell abroad will consistently have tax losses because foreign sales are not taxed but their production expenses are deductible. They can be wildly profitable but still have legitimate tax losses under a destination-based system.

${ }^{38}$ The only argument I can think of for retaining the partnership and other pass-through regimes (other than for small, sole proprietorships) is to tax inframarginal returns of low-bracket investors like tax-exempt entities, at a low rate. This does not seem compelling because these returns are, by definition, above-market returns. Moreover, even if it were a desirable goal, it would have to be weighed against the considerations in the text. 
To illustrate, consider the retailer in our running example. It purchases the widget for $\$ 70$, incurs $\$ 20$ of labor costs, and sells the widget for $\$ 100$, making a $\$ 10$ profit. Suppose that it sells the widget in Canada. Because the sale is foreign, the $\$ 100$ sales proceeds would not be taxed. The retailer would have a $\$ 70$ deductible expense for the widget, ${ }^{39}$ and a $\$ 20$ wage deduction, but no income. It would have a $\$ 90$ loss that it cannot use. If its business model is to sell widgets in Canada, it will never have taxable receipts to use against this loss.

VATs are typically refundable, which means that if a corporation has net losses, the government makes a cash payment to the corporation equal to the tax rate multiplied by the loss $(20 \%$ of $\$ 90$ or $\$ 18$ in our example). VATs can do this in part because they use an invoice system to track tax payments. The invoice system makes it more difficult to claim a loss without actually incurring one because the taxpayers cannot claim credits (the equivalent of a deduction in a cash-flow system) unless they have an invoice showing taxes were paid by their suppliers. That invoice allows the government to audit the suppliers. Fraud is not impossible in this system - there is a business of creating fraudulent invoices - but it is more difficult.

X-tax type plans, including the Brady plan, tend not to use the invoice system used in VATs which means that refundability is more difficult to administer. The likelihood of fraud may be too high to allow refunds for losses. ${ }^{40}$

A recent Treasury study tried to estimate the extent to which firms in a cash flow tax would have losses that they cannot use for long periods of time. ${ }^{41}$ They looked at firms in the ten-year period from 2004-2013. Those firms under the income tax had unused losses equal to $18 \%$ of the corporate base. (The percentage is high because the period includes the Great Recession.) Had those firms been taxed during the same period under a destination-based cash-flow tax, unused losses would have been approximately $24 \%$ of tax base. Unused losses go up by about one-third.

To the extent that losses cannot be used, the tax system will distort corporate ownership patterns, creating incentives for noneconomic conglomeration. That is, combining an exporting (or other loss producing business) with a business that has net receipts will allow

${ }^{39}$ Assuming the treatment of inventory purchases is fixed.

${ }^{40}$ For example, CARROLL AND VIARD, supra note 16 , at 78-80, argue that without invoices, an X-tax should not allow refunds.

${ }^{41}$ Patel \& McClelland, supra note 4. 
the losses to be used against those receipts. Profit-making businesses with large, unused tax losses will become takeover targets.

One possible, although limited change that might reduce the problem is to allow losses to be carried back as well as forward. Another is to expand the rules for consolidation, by, for example, allowing firms to consolidate with a greater than 50\% ownership interest rather than an $80 \%$ interest. ${ }^{42}$ Broader consolidation will make it easier for companies generating gains to consolidate with companies generating losses so that the losses can be used. Yet another is to allow losses to be used against payroll tax liability. If these changes are insufficient and there are a substantial number of businesses that consistently generate losses, an invoice system like that used in creditinvoice VATs should be considered so that losses can be refunded. ${ }^{43}$

\section{B. Tax Rates}

Tax rates are of central importance in any tax system. They effect the total revenue raised, the distributional and efficiency effects of the tax system, and tax administration. Estimating the total revenue raised and the distributional impacts requires a large model, and I leave that to others. I will focus here on the efficiency considerations for setting the corporate rate and how the corporate rate and individual tax rates relate to one other.

A headline of the Brady plan is that the corporate rate is reduced from $35 \%$ to $20 \%$. Lowering the corporate tax rate is thought to be desirable because the U.S. corporate rate is among the highest in the world. U.S. businesses are thought to be at a disadvantage relative to competitors due to this rate, and the recent spate of inversions is possibly in response to the high U.S. corporate tax rate. There is broad support for lowering the corporate tax rate, and the Brady plan fulfills this need, in spades.

One of the reasons for adopting a destination-based cash-flow consumption tax, however, is that it eliminates the need to lower corporate tax rates in response to international competition. ${ }^{44}$ The reason is that the tax base is domestic consumption. The tax rate does not affect the location of production, where corporations make their home, or where profits are located, because regardless of these choices, the tax is the same. It depends only on where consumption takes place. The central reason for a lower corporate tax rate is solved in the Brady

${ }^{42}$ CARROLL AND VIARD, supra note 16 , at 79.

${ }^{43}$ Invoice systems have a number of other important features that are explored in Weisbach, Ironing Out the Flat Tax, supra note 5.

${ }^{44}$ For additional detail, see AUERBACH AND DEVEREUX, supra note 29. 
plan by structural changes. There is, therefore, no reason to lower the tax rate to prevent corporations from relocating or because U.S. corporations face international competition from lower-taxed companies. $^{45}$

Another, independent, reason for lowering corporate tax rates is to encourage investment. Leaving aside international competitiveness (i.e., suppose the United States were a closed economy so that only domestic investment mattered), high tax rates on corporate income may make many otherwise profitable investments unwise. Lowering the corporate income tax rate improves the efficiency of corporate investments.

While this argument might be important in an income tax, it does not apply to a consumption tax. The tax rate on marginal investment is zero in a cash-flow system. There is, therefore, no reason to lower the rate to promote new investment.

Rather than setting the corporate rate based on competitiveness or investment considerations, there are three much more modest efficiency considerations that need to be taken into account when setting the corporate rate. The first is that a lower rate will reduce the size of the required currency price adjustments and the costs to firms if the adjustments are not complete and quick. That is, a low corporate rate might alleviate the concerns many importing firms have about the required currency price adjustments.

Second, and offsetting this, we may want a higher rate on economic profits. Taxes on economic profits are to a great extent nondistortive and, in some models, desirable. Third, the tax rate affects the size of the transition tax, if any. Although the effects depend on the transition rules, in general, a higher tax rate means a higher tax on existing capital on transition.

Aside from these economic considerations, there are administrative reasons for setting the rate because of how it interacts with the tax on labor income and creates incentives to recharacterize income. In a pure X-tax, the corporate rate is normally proposed to be set equal to the highest tax rate on labor income. If the corporate rate is lower than the tax rate on labor earnings, there is an incentive to pay low salaries and to take the money out as corporate earnings. Setting

${ }^{45}$ Because the corporate tax applies to domestic consumption, it could affect the location of consumption. The effects, however, will likely be very small. In particular, there may be an incentive to purchase and consume mobile and expensive items such as yachts and planes abroad to avoid a high U.S. tax, but it is not clear we should want to lower tax rates for all purchases because of these items. 
the corporate tax rate equal to the marginal rate on labor income eliminates the benefit of recharacterizing wages as corporate earnings.

Because the Brady plan has the additional tax on dividend income, however, equalizing the rates may no longer be desirable for preventing recharacterization of earnings. Instead, setting the corporate rate below the highest wage rate may be the right strategy. In particular, (1) conditional on deciding that we want a tax on dividends and other capital income at half of the rate applicable to wages and salaries, and (2) given that the corporate tax rate itself has few economic effects (as just argued), then (3) we might want to set the corporate rate to eliminate the incentive to recharacterize earnings as either salary or as dividends, which means (4) because of the tax on dividends, the corporate rate that achieves this goal will be below the tax rate on wages and salaries.

To illustrate, suppose that the Brady plan rate structure followed the standard X-tax approach and set the tax rate on corporate cash flow equal to the highest marginal tax rate on wages: the wage rate and corporate tax rate are both $33 \%$ and the tax rate on dividends is half of that or $16.5 \%$. Suppose that a worker-owned corporation has a $\$ 100$ receipt which it wants to distribute. Because the worker and the owner are the same, the money can equally be distributed as salary or as a dividend.

If the corporation pays the $\$ 100$ as salary, the owner pays $\$ 33$ in tax, leaving him with $\$ 67$. If it pays the money as a dividend, the corporation would owe $\$ 33$ in tax and the owner would pay an additional $\$ 11.06$ in dividend taxes for a total of $\$ 44.06$ in taxes, leaving the owner with $\$ 54.04$, which is less than if the money were paid as salary. There would be an incentive to pay out earnings as salary.

A $20 \%$ corporate rate, as in the Brady plan, eliminates this incentive. If the corporation were to pay out the $\$ 100$ as earnings, it would owe $\$ 20$ in tax and the owner would pay an additional $\$ 13.20$ in tax due to the $16.5 \%$ rate on dividends, leaving him with $\$ 66.80$, which is effectively the same as if the earnings were paid out as salary. The relative rates in the Brady plan, therefore, are set consistently with the goal of eliminating the incentive to recharacterize earnings.

The major problem with the relative tax rates in the Brady plan is the special cap on tax rates for pass-through entities. As argued above, the best approach would be to eliminate the pass-through regime, but if it is to be retained, the tax rate cap should be eliminated. The reason is that the tax rate cap for pass-throughs creates obvious avoidance opportunities (and has no efficiency benefits). 
In particular, the tax rate cap for pass-through income creates an incentive to recharacterize wage and salary income as pass-through income. Owners of pass-through entities could do so by paying a below-market salary (taxed at 33\%) and increasing the entity's earnings (taxed at 25\%). Moreover, individuals who work for corporations could form pass-through entities which provide services to their employers in exchange for fees rather than having their employers pay them wages or salaries. To the extent the fees can be characterized as pass-through income rather than wages or salaries, they will be taxed at a $25 \%$ rate rather than $33 \%$ rate. To prevent this avoidance, the plan would require pass-through entities to pay reasonable compensation but this rule may be difficult to enforce.

Abolishing the special rate will have few if any effects on investment but will eliminate incentive to recharacterize cash flows. If both pass-through earnings and salary are taxed at a $33 \%$ rate, it will not matter whether a cash flow is characterized as earnings or salary. There would be no need for the reasonable compensation rule and no need to incur the expense of futilely attempting to enforce it.

\section{International Issues}

International taxation has the potential to be far simpler under a destination-based consumption tax than under an income tax. The tax base under a destination-based consumption is domestic consumption. Although not always straightforward, this concept is relatively well understood and has economic meaning. It can be identified by the physical location of the individual engaging in the consumption.

The tax base in an income tax is either worldwide income, income earned in a given territory, or a mix of the two. The U.S. system, for example, might loosely be characterized as based on worldwide passive income and repatriated worldwide active income. The location of income (and related expenses), however, is not well defined. There is no underlying economic reality. As a result, the rules can be manipulated both through actual transactions and through relabeling items. Capital is highly mobile and can be packaged in an almost infinite variety of investment vehicles to exploit the rules. The rules are then made more complex to combat the avoidance, leading to yet additional more sophisticated avoidance. Moreover, if different countries have different rules, taxpayers can take advantage of the differences.

Even if we could define the location of income and even if countries agreed on the definition, the tax base has to be coordinated with other countries who may also claim to tax those same returns. For 
example, both the location where production takes place, the source country, and the location where the owner lives, the residence country, may want to tax the same income.

The end result of all this is a Byzantine tax system and very wealthy tax planners. Although it is surely the case that our current tax rules for international income can be improved, I do not think that any set of rules within an income tax would be simple and effective. The underlying concepts are ill-defined, and mobile capital makes it easy to exploit any problems.

One of the main benefits of the Brady plan is its potential to simplify the international tax rules. ${ }^{46}$ Nevertheless, the international tax aspects of the plan, particularly border adjustments, have more attention than almost any other aspect. Below I examine the problem of border adjustments and then turn to other international tax issues.

\section{Border adjustments}

Recall that the Brady plan includes border adjustments. Exports are not taxed, which means that an exporter will have domestic costs but no taxable cash flow on its sales, generating a net loss. In our running example, if the retailer purchases the good for $\$ 70$ and sells it abroad for $\$ 100$, it does not include the $\$ 100$ but may deduct the $\$ 70$, generating $\$ 14$ of tax savings. This $\$ 14$ of tax savings is the border adjustment.

Imports are not deductible. Importers will have taxable receipts when they sell their imports in the United States but will not have deductible costs, which means that the full value of goods when imported will be taxed. If the retailer imported the good for $\$ 70$ and sold it in the United States for $\$ 100$, it would not be able to deduct the $\$ 70$ but would be taxed on the $\$ 100$. For the moment, leaving aside the wage deduction and wage tax (which offset) the importer would owe $\$ 20$, consisting of the $\$ 6$ tax on the value it added in the United States and the $\$ 14$ tax on the value of the good when imported. The $\$ 14$ tax on import is the border adjustment on import. That is border adjustments are the $\$ 14$ rebate on export for costs incurred in the United States and the $\$ 14$ tax on import for value added abroad.

${ }^{46}$ Note, however, that as discussed in Part IV.A., the Brady plan seems to retain many elements of an income tax (possibly inadvertently). If these elements are part of the final legislation, many of the current law rules for taxation of international income would also have to be retained. The vast simplification of international tax rules that comes with a consumption base requires consistent use of a consumption base. 
As noted, economists believe that in equilibrium, a destinationbased system (i.e., a system with border adjustments) and an originbased system (one without border adjustments) are equivalent except for how they tax inframarginal returns and on transition. As a result, notwithstanding much of the rhetoric surrounding border adjustments, a decision to have border adjustments should be made based on administrative considerations rather than a belief that one system or the other promotes U.S. businesses relative to foreign businesses. ${ }^{47}$

To understand the administrative considerations, I list below the benefits and costs of having border adjustments. After going through the costs and benefits, I provide an overall evaluation.

The key benefit to border adjustments is that they reduce or even eliminate the transfer pricing problems of current law and that an origin-based consumption tax would face. If the manufacturer in our running example sells the widget to a foreign retailer in an origin-based system, the sales price determines how much tax the manufacturer owes. If the manufacturer sells the widget to the retailer for $\$ 50$ (when its fair market value was $\$ 70$ ), it eliminates $\$ 20$ from its tax base. If the manufacturer and the retailer are commonly owned, there is no economic cost to lowering the price, generating the transfer pricing problem. With a destination-based system, the sale to the foreign retailer is not taxed regardless of the price, so there is no transfer pricing problem. A similar logic holds for imports: in an origin-based system, raising the price of an import reduces the U.S. tax base while in a destination-based system, it has no effect.

Eliminating transfer pricing problems is a substantial benefit. Recent estimates are that by 2012, the United States was losing between $\$ 77$ and $\$ 110$ billion annually due to transfer pricing manipulation. ${ }^{48}$ This is a large sum by any measure. Moreover, it does not include the planning costs, such as paying lawyers, accountants, and bankers, and the economic distortions, such as the costs of relocating capital or individuals to increase the likelihood that transfer prices will be respected.

${ }^{47}$ If the United States is a net importer during the 10-year budget window, as is expected, border adjustments will be scored as raising revenue. Although I have not seen any official revenue estimates, I understand that this revenue is being used to pay for other aspects of the plan. Note, however, that to the extent that border adjustments are imposed at a time when the United States has a trade deficit, they lose rather than raise money in present value terms. Any claim that border adjustments raise money is due to an artifact in the scoring rules.

${ }^{48}$ Kimberly A. Clausing, The Effect of Profit Shifting on the Corporate Tax Base in the United States and Beyond, 69 NAT'L TAX J. 905, 905-34 (2016). 
A second potential benefit of border adjustments is that they eliminate the incentives seen in origin-based systems for tax competition. In particular, in an origin-based system, countries have an incentive to lower tax rates to attract businesses that have mobile, source-based, inframarginal returns. This incentive goes away with a destination-based tax because the location of production has no effect on the level of the tax.

There are three key of costs of a destination-based system. The first, which is unique to an X-tax structure like the Brady plan, is that border adjustments under such a structure may be contrary to WTO law. The problem can be thought of as one of substance versus form. If the income tax elements of the corporate tax discussed above, such as the non-deductibility of land and inventory are eliminated, the substance of the Brady plan with border adjustments is entirely consistent with WTO law. ${ }^{49}$ It is effectively the same as destinationbased tax systems used throughout the world. The form, however, may be inconsistent with WTO law. The legal question is whether a WTO panel would follow the substance or the form of the law.

The "form" problem is that under the WTO Subsidies and Countervailing Measures Agreement, a tax can be border adjustable only if it is an "indirect" tax and not if it is a "direct" tax. A direct tax is a tax on "wages, profits, interests, rents, royalties, and all other forms of income." An indirect tax includes a VAT and all taxes other than direct tax. Moreover, border adjustments for an indirect tax are allowed only if they do not exceed the amount of indirect tax levied on like products when sold for domestic consumption. I interpret this latter requirement as a requirement that border adjustments are accurate: rebates on exports cannot exceed previously imposed taxes and taxes on imports cannot exceed taxes that would be imposed domestically.

The Brady plan and similar plans like the X-tax, look like a VAT, which is an indirect tax, except that they have a deduction for wages at the business level and tax wages to individuals. The question is whether this treatment of wages makes the Brady plan a direct tax. There seems to be little or no jurisprudence giving further meaning to these terms, and there are no tax systems like the Brady plan or the Xtax to use as a comparison. Many commentators, however, believe that the best reading of these terms is that the Brady plan would be a direct tax, ineligible for border adjustments.

\footnotetext{
${ }^{49}$ If these elements are retained, it is hard to see how border adjustments would be consistent with the WTO.
} 
One reason why commentators believe that the Brady plan would be a direct tax is that because of the wage deduction, border adjustments would be inaccurate. They could exceed the indirect tax levied on like products when sold domestically. Although the accuracy requirement is distinct from the "indirect" requirement, the two are likely related: the inaccuracy of the border adjustments arises because the tax is not purely at the business level.

To illustrate why border adjustments would be inaccurate, consider our retailer who sells the widget for $\$ 100$ to a foreign consumer. The retailer deducts $\$ 70$ and gets a rebate of $\$ 14$. The manufacturer that sold the good to the retailer, however, has a tax base of only $\$ 20$ : it has $\$ 70$ of receipts and $\$ 50$ of labor costs. It pays a tax of $\$ 4$. The $\$ 50$ of labor costs are taxed to the wage earners. The wage earners, however, do not necessary pay $\$ 10$ in tax. Depending on their rates, they may pay more than that or less. If they pay less, the retailer's border adjustment of $\$ 14$ exceeds the taxes paid at prior levels of production. Moreover, because only indirect taxes count when computing accuracy, and because the wage tax is not an indirect tax, there has only been a $\$ 4$ indirect tax on the good even though the rebate is $\$ 14$, clearly violating the accuracy requirement.

This argument, however, is purely formal rather than substantive because we can just change the labels without changing the tax that is levied and make the system unquestionably legal. Suppose that instead of giving businesses a deduction for wages and salaries and taxing workers on their wages and salaries, we instead imposed a normal VAT, with no deduction for wages. Wage income would then be taxed at the flat VAT rate rather than the desired progressive rates. This VAT could clearly be border adjustable because it is an indirect tax and the border adjustment would be accurate.

To make the taxation of wage income progressive, we can add a tax credit for low-income workers which offsets the VAT in the desired amounts, and, for high-income workers (if their marginal tax rate on wages exceeds the VAT rate), impose a tax on those wages to make up the difference. For example, if the VAT rate is $20 \%$ and we want high-wage earners to pay $33 \%$, we could impose a tax rate of $16.25 \%$ on their wages. The corporation would pay them $\$ 80$ after paying the $20 \%$ tax. A $16.25 \%$ tax on the $\$ 80$ of wages would be $\$ 13$, so the total tax would be $\$ 33$, or $33 \%$ as desired. Similarly, we could offer low-wage workers a credit, such as an expanded earned income tax credit or an offset to payroll taxes, to give them the required combined tax rate. This labor income tax/credit system would be 
entirely separate from the VAT. It would, therefore, not affect the border-adjustability of the VAT. It is simply a separate, progressive wage tax.

This is how European systems work. They have flat rate, border-adjustable VATs and separate progressive income taxes. Under the X-tax and the Brady plan, the two systems are combined because of the wage deduction at the business level and matching inclusion to workers. It is only because the two system are combined that there is an issue of WTO legality, but this is a mere formality rather than a substantive difference.

The question, therefore, is whether the substance of the Brady plan should prevail or its form. I am not sufficiently expert in WTO jurisprudence to have a view on the likelihood of success. Some authors conclude that the border adjustments would not be allowed under the WTO rules, but these authors rely on the formal structure of the plan. ${ }^{50}$ To get a sense of the risks, it would be nice to have a better understanding of whether, and when, the WTO is able to look at the substance of a law rather than its formal rules. There is nothing in the Brady plan that violates the substantive goals of the WTO.

Rather than confronting the WTO and having to make legal arguments about substance versus form, we could simply adopt the VAT/wage tax structure suggested above. For reasons that are unclear to me, however, actually adopting a VAT seems to be politically untenable even though, a just demonstrated, there is no economic difference between what is going proposed in the Brady plan and the modification just described.

An alternative is to modify the labels in the Brady plan to increase the likelihood of compliance while not formally adopting a VAT. For example, we could retain the current structure but require wage withholding at the corporate rate, rather than setting wage withholding based on each individual's tax rate. In our example, if wage withholding were mandatory and always at a $20 \%$ rate, the manufacturer in the example would have remitted $\$ 14$ in tax, so the retailer's rebate will match tax remittance at prior levels of production. In effect, corporations would be required to remit as taxes the same amount that they would remit under a VAT, without exception. The

${ }^{50}$ Avi-Yonah \& Clausing, supra note 4. 
only difference is that a portion of the remittance is called a withholding tax rather than a corporate tax. ${ }^{51}$

The second cost of border adjustments is the cost of uncertainty about currency adjustments. Recall that the switch from current law to a destination-based system requires the dollar to appreciate. Consider for example, an importer who currently buys goods from abroad for $\$ 95$ and sells them domestically for $\$ 100$, making a $\$ 5$ profit. Under current law, it can offset the $\$ 95$ of costs against its $\$ 100$ receipts and pay tax on the net. If the tax rate is $20 \%$, the importer is left with $\$ 4$. With a destination-based system, it would not be able to deduct the $\$ 95$ cost of import and it would owe $\$ 20$ of tax on its $\$ 100$ receipt. If nothing changed, the tax would greatly exceed its profits.

The expectation is that the dollar would appreciate. With a $20 \%$ tax rate, the dollar would appreciate by $25 \%$, so that the importer could purchase the good for $\$ 76$. If this happens, the importer would have $\$ 100$ in receipts, pay a $\$ 20$ tax and be left with a $\$ 4$ after-tax profit. If this happens completely and quickly, nobody would be worse for the wear. The concern is that this will not happen quickly enough or completely. Importers are reluctant to rely on economic models when their entire business is at stake.

We have more than economic models, however, to give us confidence that the currency adjustments would, in fact, occur. Every VAT in the world relies on these currency adjustments. If they did not occur, importers in countries with VATs would face exactly the same problem that importers are worried about with the Brady plan. There are good reasons to be confident in the currency adjustments.

The real issue is transition. If the adjustments are slow or uneven, importers could be hurt. While the currency market is deep and liquid, so that one would expect the overall adjustments to be fast, some countries have their currencies pegged to the dollar or attempt to manage their currencies relative to the dollar. These countries would have to repeg or change their dollar targets. This might not happen

${ }^{51}$ One cost of this approach is that withholding will be too high for lowincome workers. To the extent these workers may be cash constrained, withholding at too high a rate may not be viable. Fixing this problem could be done by reducing withholding for payroll taxes or allowing an advance rebate implemented through debit cards. Michael Graetz considered both in his tax proposal. MICHAEL J.

GRAETZ, 100 MiLlion UNNECESSARY RETURNS: A SiMPLE, FAIR, AND COMPETITIVE TAX Plan FOR THE UNITED STATES (2008). 
instantly. ${ }^{52}$ Moreover, oil is traded in dollars, so currency adjustments will not affect the relative price of oil.

Because I view the problem of currency adjustments as one of transition, I discuss mechanisms to ease the transition in Part IV.H., where I discuss transition issues more generally. Note, however, that the risk of a rocky transition is a substantial cost of border adjustments. Incomplete or slow currency adjustments would be disruptive.

The third problem with border adjustments is enforcement. VATs have experienced two enforcement problems with their border adjustments. One is fake exports used to obtain tax rebates. The Brady plan is not refundable, unlike most VATs, which reduces this problem. A second problem is avoidance of the tax on import. This is a particular problem for intangibles such as purely electronic goods sold over the internet (e.g., software, videos, and computer games) and services provided from abroad (e.g., accounting or legal services provided remotely). To tax these items, we would need to impose a $20 \%$ excise tax on their purchase. Collecting such a tax may be difficult, and evasion levels may be high. One central problem with collecting an excise tax on import is that remote sellers do not have a permanent establishment in the United States, so imposing the tax on sellers may not be feasible. Imposing the tax on purchasers, which is what states try to do, ineffectively, with use taxes, would also not be simple.

One can weigh these costs and benefits differently. For example, the weight given to the WTO problems may depend on your reading of WTO law, views on the consequences of an adverse ruling, and the feasibility of modifying the plan to reduce the risk of an adverse ruling. Importers naturally heavily weigh the risk of slow or incomplete currency adjustments.

My overall view, which I hold weakly rather than strongly, is that I believe it is worth having border adjustments. The WTO problem and currency adjustments are one-time problems - serious ones to be sure - that with careful management can likely be overcome. Relabeling taxes can reduce the formal problem with compliance with the WTO without changing the substance of the tax law. Transition rules can reduce the risk of slow or incomplete currency adjustments. Transfer pricing is a permanent problem. I would rather try to get over

\footnotetext{
${ }^{52}$ Perhaps one should not underestimate the ability of people or countries to be irrational, but it is hard to see a reason for not repegging or retargeting. Moreover, failing to repeg or retarget would impose tremendous economic pressure on these countries.
} 
the one-time problems to fix a serious and growing problem that will last indefinitely.

\section{Other international tax issues: treaties and creditability}

Countries that impose world-wide taxation on domestic companies typically allow the companies to claim a foreign tax credit for income taxes paid abroad. Credits are restricted to income taxes, which means that taxed paid under the Brady plan may not be creditable. Some have suggested that this may be a problem.

It is not clear, however, how big the problem would be because the net present value tax in a cash-flow system is zero. The initial reduction in credits when an investment is expensed exactly offsets the increase in credit from the U.S. tax on the return. There would be no need for a crediting system because there is no net tax.

Separately, the business portion of the Brady plan might not qualify as an income tax under our existing network of treaties because the base is consumption. VATs, for example, do not quality as income taxes for treaty purposes.

Treaties are important to U.S. businesses investing abroad because they provide relief from foreign withholding taxes, scale back the tax reach of foreign countries, and prevent discriminatory treatment of foreign investment. Foreign businesses, in return, receive similar benefits when investing in the United Sates.

The question is whether foreign nations will find it in their selfinterest to continue their treaty relationships under the Brady plan. Because it eliminates U.S. source-based taxation, the Brady plan may, by statute, give foreign investors many of the benefits they currently receive by treaty. As a result, treaty partners may not see any need to give up any of their source tax revenues, and, therefore, not see any need to continue their treaties with the United States.

Foreign nations will have to make the determination of whether they wish to continue their treaty relationships with the United States. In the meantime, the United States should continue to treat the treaties as applying. Moreover, the plan should maintain the withholding tax on dividends, so that if a foreign nation terminates their treaty with the United States, the full withholding tax would apply, thereby creating an incentive for foreign nations to continue to treat the treaty as binding. Because of treaty nondiscrimination provisions, the United States may not be allowed to impose a withholding tax with treaty countries. If a country were to terminate its treaty with the United 
States, the withholding tax would kick in, creating an incentive not to terminate the treaty. ${ }^{53}$

\section{Financial Flows}

The plan as written distinguishes between interest expense and payments on real assets. If it were fully R-based, it would distinguish financial flows from real flows. Regardless of which approach is taken, making these distinctions will generate a number of problems. ${ }^{54}$

\section{Interest $v$. other payments}

Suppose that the plan only disallowed net interest deductions but otherwise taxed financial flows, which is how the current draft reads. ${ }^{55}$ The plan would then need rules to determine when a flow is "interest" instead of something else. This problem exists under current law but would be worse under the Brady plan because the consequences of being labeled interest would be more severe.

To illustrate, suppose that a business wanted to borrow $\$ 100$ at a $10 \%$ interest rate for one year. If it used a financial instrument formally labeled debt to borrow the $\$ 100$, the $\$ 10$ of interest that it pays would be non-deductible. Suppose instead that it borrowed the following way: it sells short $\$ 100$ of Treasury securities and simultaneously enters into a forward contract to purchase Treasury securities in one year for $\$ 110$. The cash flows on this second transaction are identical to the flows on formal borrowing. The second, however, uses the form of the sale and purchase of securities rather than of a debt instrument.

The combined sale and repurchase might be recharacterized as a borrowing because the flows precisely match those of a borrowing. If so, however, it would be straightforward to make the flows mismatch one another to avoid recharacterization but without changing the economics significantly.

There will be no easy way around this problem. Any set of flows where payments come in before they go out has implicit interest. Absent an attempt to impute interest to all flows, there will be ways to hide interest expense in real or other financial flows and generate deductions for what is economically interest expense.

Real $v$. financial flows

${ }^{53}$ See Harry Grubert \& T. Scott Newlon, The International Implications of Consumption Tax Proposals, 48 NAT'L. TAX J. 619, 642 (1995).

${ }^{54}$ For additional detail, see, Chapter 6 in CARROLL AND VIARD, supra note 16 , at $81-101$.

${ }^{55}$ As discussed above, I am assuming that to the extent the plan taxes financial flows, it does so on an income tax basis, not a cash-flow basis. 
Suppose instead that the Brady plan were to take the more conventional approach used in VATs and in X-tax proposals and ignored all financial flows. Under this approach, the tax system would have to distinguish financial flows from real flows. Many transactions, however, have elements of both.

A typical case is the sale of a good on credit. For example, suppose a retailer sold a good with a fair market value of $\$ 100$ to a customer and the customer agreed to pay $\$ 110$ in one year's time. If interest income is not taxed but sales proceeds are, the retailer will want to characterize the transaction as producing a $\$ 100$ real inflow (which is taxable) and a $\$ 10$ interest receipt (which is not taxable). If the value of the good cannot be readily determined, the retailer will have an incentive to overstate the interest, for example, by claiming the value of the good is only $\$ 95$ and there is $\$ 15$ of non-taxable interest income, reducing the tax base by $\$ 5$.

Problems would also arise with transactions such as forward contracts that can be either cash settled or physically settled. For example, suppose that a corporation entered into a contract for the purchase of a unit of pork bellies in one year's time for $\$ 100$. If pork bellies went up in price over the course of the year, the corporation would have a gain on the transaction. In this case, it could cash settle the contract and report it as an excludible financial flow. If pork bellies went down in price, the corporation would have a loss, and it could physically settle the contract, reporting a deductible loss. If the other side of the contract is a taxable entity, its incentives would be the flip, so that any tax advantage to one party is a disadvantage to the other. If, however, the other side were not taxed or were taxed differently than the corporation (say because it is a financial institution using a special regime for financial institutions), their incentives might not offset.

The underlying problem is that there is no economic distinction between real and financial flows. The distinction is a tax distinction. Nevertheless, VATs around the world draw this line, so there is substantial experience with the problems that arise. Solutions used in VATs should be considered for the Brady plan.

\section{Financial institutions}

Regardless of which approach is taken, the system will have a problem taxing financial institutions. Suppose that all financial transactions are ignored. Financial institutions buy and sell (or issue) securities and other financial instruments, incurring labor and capital costs to do so. If financial flows are ignored, all they would have would be deductible costs for labor and physical capital (such as 
buildings and computers). They would generate losses every year even if they are wildly profitable.

Financial institutions are a substantial portion of the U.S. economy. They include commercial and investment banks, property, casualty, and life insurance and reinsurance companies, securities brokers and dealers, mutual funds, market makers, and traders such as hedge funds. All of these entities would be effectively untaxed, or even generate net losses, in a pure R-based system.

An R-based tax system will need a special regime for the taxation of financial institutions. A likely candidate is to tax financial institutions on all flows (other than with respect to stock), both real and financial. ${ }^{56}$ This system is known as an $\mathrm{R}+\mathrm{F}$ system and was original devised by a UK tax reform commission known as the Meade Commission. ${ }^{57}$ Like a cash-flow system on ordinary businesses, an $\mathrm{R}+\mathrm{F}$ system taxes economic profits and, depending on the transition rules, existing capital.

Putting financial institutions on an $\mathrm{R}+\mathrm{F}$ basis requires a definition of financial institutions. This will not be straightforward both because of the wide variety of financial institutions and because ordinary businesses may engage in a large number of financial transactions (such as lending to customers and hedging their risk) so that it may sometimes be difficult to tell when a business is a financial institution.

\section{E. Corporate Transactions}

The current income tax has a substantial body of law governing corporate transactions such as mergers, stock acquisitions, and corporate divisions. These rules were developed within an income tax and would need to be rethought if the corporate tax base is consumption.

Consider a corporation that has assets valued at $\$ 100$ and has a basis in the assets of, say, $\$ 70$. Under current law, if it were to sell all of its assets to another corporation, it would, without special provisions, owe a tax on its $\$ 30$ of gain. If, however, the asset sale is done just the right way - meeting an endless list of seemingly arbitrary rules - the reorganization provisions of current law allow the corporation to avoid paying tax on its gain. Instead, the gain is transferred to the buyer by giving the buyer a $\$ 70$ basis in the assets rather than a basis equal to its purchase price of $\$ 100$. Similarly, if the

\footnotetext{
${ }^{56}$ For a discussion, see Peter Merrill \& Chris Edward, Cash-flow Taxation of Financial Services, 49 NAT'L. TAX J. 487 (1996).

${ }^{57}$ INST. FOR FISCAL STUDIES, supra note 10, at 230-245.
} 
corporation were to spin off the assets by incorporating them and distributing the stock of the new corporation to its shareholders, special rules, with yet more complex and arbitrary requirements, allow the spin-off to defer taxation.

In a consumption tax system, there is, by operation of the system and without special rules, no net tax on the sale of the assets from one business to another. In the example, the selling business would have a taxable inflow of $\$ 100$ and the buyer would have a deductible outflow of $\$ 100$, netting to zero. There is no need for the reorganization rules.

Moreover, even if desired, there would be no easy way to retain the equivalent of the reorganization rules in a cash-flow system. The current rules operate by not taxing the target corporation and not giving the buyer basis for its costs. Instead, the buyer inherits the target's basis. There is, however, no concept of basis in a cash-flow system. Not taxing the seller and not allowing the buyer a deduction does not achieve the same thing as the current law reorganization rules unless there is some way to shift the equivalent of basis - the deduction the seller had when it purchased its assets - to the buyer. In particular, in an income tax, we shift the capitalized cost of the seller's assets to the buyer by transferring the seller's basis to the buyer. With a cash flow system this would be very difficult because there is no basis. The seller will have deducted the $\$ 70$ when the assets were purchased, which could have been many years ago. In fact, taxing the sale to the buyer and giving the seller a deduction can be thought of as the consumption tax equivalent of the reorganization rules because this treatment effectively shifts the prior deduction to the new owner of the assets in the same way that the income tax rules shift the basis.

There are two other effects of the reorganization rules under current law. The first is that they allow shareholders to defer taxation of gains when they exchange their shares of a target corporation for the shares of a purchasing corporation. Because the Brady plan retains the individual-level income tax, the rules would continue to matter for shareholders. It is not clear, however, why it is desirable to allow shareholders to exchange stock in one company for stock in another without paying tax. Moreover, even if one could identify circumstances when it is desirable to allow shareholders to defer taxation, it is unlikely that those circumstances would be anything like the cases allowed under current law. And finally, with a low tax rate on capital income, there is little reason to have complex rules that allow deferral. 
The other effect of the reorganization rules is that they allow corporate tax attributes such as net operating losses and unused tax credits to be transferred from the buyer to the seller. If asset sales were fully taxable under the Brady plan, tax attributes would not transfer from target corporations to purchasers. If the target were to liquidate, moreover, the attributes might disappear. Structuring the same transaction as a stock purchase would mean that the attributes would remain with the target corporation and potentially be usable by the purchasing corporation via consolidation. The result would be a difference between stock transactions and asset transactions.

Given that asset purchases in a cash-flow system do not generate net tax, the key effects of reorganization rules would be to defer shareholder gain - something I view as undesirable - and to reduce the disparities between asset sales and stock sales with respect to the carryover of attributes. Given how much less is at stake, the best approach, in my view, is to make all corporate transactions taxable and all exchanges of shares taxable, with perhaps an exception for recapitalizations. Attributes would carry over in stock transactions but not asset transactions. Alternatively, greatly simplified rules could be adopted to allow attributes to be transferred. For example, attributes could be transferred in any transaction in which two companies merge or in which one purchases substantially all of the assets of another (regardless of the consideration). All the other ornate concepts of the current law reorganization rules could be eliminated.

The same arguments apply to the rules governing contributions to corporations. These rules rely on shifting the basis of assets to the corporation. Without a basis system, these rules may no longer make sense. Moreover, in this case, there is no attribute transfer under current law, so special attribute transfer rules would not be needed.

The rules defining dividends will also likely need to be revised. The current rules determine whether a distribution is a dividend by whether it comes out of corporate earnings and profits. The earnings and profits account is determined on an income basis. While an income-based earnings and profits account could be retained, doing so would mean that for tax purposes, corporations must compute both income and consumption tax bases and would require retention of many income tax rules.

An alternative would be to compute earnings and profits on a cash-flow basis. If this approach were taken, it would only make sense to use a cumulative account rather than the current approach of looking to a current account (and then a cumulative account). To illustrate, suppose that a corporation purchases an asset for $\$ 100$ in year 1 and 
receives $\$ 110$ in year 2 . On a cumulative basis, it has $\$ 10$ of earnings which would support a $\$ 10$ dividend. Looking only at year 2 (so looking at the current earnings and profits account, which is what current law does) would give the corporation $\$ 110$ of earnings, which would then produce a $\$ 110$ dividend, which is far excess of any measure of corporate earnings.

The current corporate tax system also has a number of rules designed to prevent losses from being transferred. For example, if a corporation changes control, it may be limited in its ability to use losses in the future. With a cash flow system, however, losses will be, for the most part, freely transferable simply because of the way a cashflow system works. Consider a company with a $\$ 100$ net operating loss. The company can transfer the loss simply by selling a $\$ 100$ asset. The selling company will have $\$ 100$ of taxable receipts, which it can use against the loss and the purchasing company will have a $\$ 100$ deduction, effectively transferring the loss.

The Brady plan allows indefinite carryforward with interest, so the incentive to transfer losses will be reduced as compared to current law. On the other hand, under a destination-based cash-flow system, some businesses may be unlikely to be able to use losses for the indefinite future even if they are profitable. In these cases, incentives to transfer losses may remain. Given that loss transferability is built into the structure of the system, it may not be desirable to try to retain the current rules against loss transfers.

In short, one of the major simplification benefits of the Brady plan (if amended to consistently tax consumption) would be to revise and repeal most of the provisions governing major corporate transactions. (And if the pass-through regimes are repealed, the Brady plan could eliminate those rules as well.) These rules are not mentioned in the current draft plan. As the plan progresses, this simplification opportunity should be taken.

\section{F. Deferral}

The Brady plan taxes dividends, interest, and capital gains received by individuals at a rate equal to half of the tax rate applicable to other income. I assume, although the plan is silent, that the reduced rate also applies to flows from similar investments, such as from futures and forward contracts, swaps, options, and other financial instruments as well as non-business investments in property such as speculation in land, minerals, and collectibles.

Combining this tax on capital income with a cash-flow business-level tax may be challenging. The reason is that capital investments at the business level bear no tax (because of the cash flow 
system). As a result, funds can be retained at the business level until needed for consumption, at which point they would be withdrawn and taxed. The effect is elective deferral of capital income, allowing capital income to grow tax free during the period of deferral.

The Bush tax commission's Growth and Investment plan had the same problem. They suggested that one or more of current law's anti-deferral regimes would be needed, but provided no details on how such a system would work. A serious problem with applying these regimes is that they will not be able to apply to funds that are genuinely invested in a business. They try to find "sham" investments, or incorporated pocketbooks, where individuals use shell corporations to hold funds and get deferral without really investing in active businesses. In the Brady plan, however, the tax rate on marginal investments is zero, so if funds are genuinely invested in a business, the marginal tax rate on the investment will be zero. Anti-abuse rules that disallow the zero marginal rate would be contrary to the basic structure and intent of the tax system.

I do not see an easy solution to this problem. There is a basic conflict in the plan between having a cash-flow tax at the business level and a tax on capital income at the individual level. The following approaches might reduce the problem it to some extent:

- Eliminate stepped-up basis at death. The plan repeals the estate tax but does not mention stepped-up basis at death. Proposals to repeal the estate tax are often accompanied by repeal of stepped-up basis at death. Getting rid of stepped up basis at death reduces the advantage of deferral.

- Lower the tax rate on capital income even further. The current plan imposes a top tax rate of $16.5 \%$ on capital income. If the rate is even lower, the incentive to plan to get deferral correspondingly goes down. (To retain progressivity, other rates would have to be adjusted.)

- Impose a mark-to-market regime for publicly-traded securities at a low tax rate.

- Instead of a mark-to-market regime, impose a regime that is economically equivalent to a mark-to-market regime, such as a system that imputes income based on an assumed return.

The only one of these solutions that really solves the problem is a mark-to-market regime or an equivalent. If such a system is not feasible, the best alternative might be to abandon the tax on capital income at the individual level and instead adopt a pure X-tax. The Bush commission studied (but did not propose) a pure X-tax. They 
showed that a pure X-tax can be distributionally and revenue neutral, so there is little need for the additional tax on capital at the individual level. The tax on capital income creates terrible enforcement problems and will distort behavior as people seek to avoid it. Moreover, to the extent it can be enforced, it is inefficient relative to a pure consumption tax (for, apparently, no distributional benefit).

\section{G. Other Individual Tax Provisions}

The Brady plan indicates that it may revise many of the provisions that affect the tax liability of individuals, including the mortgage interest deduction, the charitable deduction, the retirement savings provisions, and the exclusion of employer provided health insurance. To a great extent, the choices made with respect to these provisions are independent of the consumption tax structure of the plan. Each raises complex issue that may have large effects on the relevant sectors of the economy. Because the choices for these provisions are largely orthogonal to the structural issues raised by the Brady plan and because the choices are so complex, I do not discuss these issues here, except for following three brief points.

First, if interest income is taxed at the individual level at half the individual tax rate and mortgage interest is deductible at the full rate, there will be an obvious arbitrage: increase the size of your mortgage and invest the funds in debt instruments. Interest received will be taxed at half the rate interest is deducted, generating net tax losses for no real activity.

The same concern applies to investment interest expense. If investment interest expense is fully deductible but interest income is taxed at only half that rate, there are obvious arbitrages. The plan makes clear that net interest expense is not deductible for businesses but says nothing about individuals and investment interest expense.

Second, the plan eliminates the state and local tax deduction (as well as other itemized deductions other than home mortgage interest and charitable donations). There is a substantial literature on the merits of the state and local tax deduction. ${ }^{58}$ A decision to repeal it will have important effects on the structure of local government and deserves careful consideration.

Third, the plan seems to retain payroll taxes. For many families, payroll taxes are the dominant tax. They are also currently about one-third of federal taxes. When we think about the tax rates

${ }^{58}$ For example, Martin S. Feldstein \& Gilbert E. Metcalf, The Effect of Federal Tax Deductibility on State and Local Taxes and Spending, 95 J. POL. ECON. 710 (1987). 
applicable to wage income, we need to add in payroll taxes. For example, payroll taxes may alter the incentives to recharacterize capital income as wage income or vice versa.

\section{H. Transition}

The Brady plan says nothing about the transition to the new system other than it will provide clear rules "to serve as an appropriate bridge from the current tax system to the new system." The transition to a consumption tax, however, is one of the most important and most difficult aspects of consumption taxation. The literature on transition is massive, and I can only touch on key points here. ${ }^{59}$

\section{Basic economics of transition}

The transition to a consumption tax is often said to impose a tax on existing capital. There are two ways to see why. The first is definitional: existing capital is a source of consumption. If you have money in the bank, you can withdraw it and buy things. Therefore, if the tax is to be on all consumption, it must be on existing capital.

The second is transactional. Suppose that we have an income tax and that you own an asset worth $\$ 100$ that you purchased for $\$ 100$. Under the income tax, you would have a basis in the asset of $\$ 100$ and if the income tax remained in place, you could sell the asset for $\$ 100$ without tax. Suppose that at midnight tonight, we switch to a cashflow consumption tax in which all purchases are deductible and all inflows are taxed. Under this system, there is no tax basis. The full amount of any inflow is taxed. The next day, you sell your $\$ 100$ asset. You have a $\$ 100$ inflow, which would be fully taxed. The cash-flow tax effectively taxes all existing capital when the capital is sold and used for consumption.

Whether this is desirable is not a matter of definitions or transactional rules. The question is whether it has desirable efficiency or distributional effects. The argument that it is efficient is that if the switch is unanticipated, the tax on existing capital is lump sum. Of course, transition would almost surely be anticipated, so people will take steps to avoid it, such as by accelerating their consumption to be before transition and deferring investments to be after transition. Moreover, if the new consumption tax has loopholes, there will be incentives to use those loopholes to avoid the tax on existing capital. Nevertheless, while the tax may not be lump sum, it may be reasonably efficient. A tax on transition on existing capital would also have

${ }^{59}$ For a survey of the literature, see Louis Kaplow, Capital Levies and Transition to a Consumption Tax, in INSTITUTIONAL FOUNDATIONS OF PUBLIC FINANCE 112 (Alan J. Auerbach \& Daniel Shaviro eds., 2008). 
desirable distributional properties because most existing capital is held by wealthy individuals.

On the other hand, a tax on existing capital will likely raise vociferous objections. Going back to the example, you bought the $\$ 100$ asset with after-tax cash - that is why you have basis in the asset. If you are asked to pay tax again on the $\$ 100$, you will surely object, even if the tax is under a new system.

\section{Existing basis}

The reason cash-flow systems tax (or can tax) existing capital is because after the transition date, they ignore basis that was created under the now-repealed income tax. In the example given above, you had a $\$ 100$ basis in your asset before the transition. After the transition, when you sold your asset for $\$ 100$, you had a $\$ 100$ cash inflow and could not use your income tax basis against the inflow because the new system does not use basis to compute tax liability. We can, therefore, think of the tax on existing capital as arising because basis under the income tax does not count under a consumption tax.

The central issue on transition, therefore, is whether businesses can use their existing basis. The extent to which businesses can use their existing basis determines the extent of transition relief or transition tax. Giving transition relief by letting taxpayer use existing basis, however, means that it could be years or decades before the system is fully on a cash-flow basis. Moreover, transition relief will be very expensive given the size of the existing capital base, which means that tax rates would have to be much higher than without transition relief.

The Brady plan says nothing about this, although I think the best reading of the text is that businesses will continue to be able to use existing basis. The text simply says that new investment will be expensed.

The Bush tax commission tried to take a middle course. They allowed businesses to continue to use their existing depreciation allowances but phased them out over five years. For example, in the second year of the new tax, businesses would be able to use $80 \%$ of the basis that they could have used under an income tax, $60 \%$ in the third year, and so forth. This approach reduces the extent of transition relief and also ensures that the income tax rules - basis and so forth can be eliminated after five years rather than having to be retained indefinitely. 
A way to generalize this system is to allow taxpayers to a recover fraction of their basis in all of their assets (not just depreciable assets) on a fixed schedule. Taxpayers would have to declare (and document) their basis and then could recover it (or a fraction) over a set period of time unrelated to the sale of their assets. This would allow any level of desired transition relief depending on the allowed fraction and would allow the system to move immediately to a cash flow basis, eliminating the need for income tax rules. Alternatively, basis could remain attached to assets so that it can be used when assets are sold, but would decline over a set period of time.

\section{Tax rate changes}

The transition effects of a tax rate change are exactly the same as the transition effects from the initial introduction of a cash-flow tax. Consider the example of the $\$ 100$ investment, and suppose, now, that the investment was made under a cash flow system when the tax rate was $20 \%$. The investment produced a $\$ 20$ tax saving. A year from now, the investment is sold for $\$ 110$. If the tax rate were still $20 \%$, the tax due would be $\$ 22$, which is the future value of the $\$ 20$ of tax savings. Suppose, however, that in the interim, the tax rate was increased to $30 \%$. The tax due would now be $\$ 33, \$ 11$ more than under the $20 \%$ tax. This $\$ 11$ ( $\$ 10$ in present value terms) is a $10 \%$ tax on existing capital. It is a tax on existing capital equal to the tax increase of 10 percentage points. The opposite holds if tax rates go down. Taxpayers will receive a subsidy on existing capital equal to the amount by which taxes go down.

Transition relief is relatively easy for the switch from an income tax to a consumption tax because taxpayers can be allowed to continue to use their existing basis. The problem is much more difficult once taxpayers are in a cash-flow system and tax rates change because there is no basis to use. There is no straightforward way to provide transition relief.

Failing to provide transition relief for tax rate changes, however, may make the system less efficient because there would be an incentive to time transactions to take advantage of rate changes. In particular, if it is anticipated that rates will go up, there will be an incentive to accelerate consumption to avoid the transition tax. If it is anticipated that rates will go down, there will be a corresponding incentive to delay consumption. These timing effects are inefficient because the tax system is causing individuals to accelerate or defer their consumption.

Most cash-flow tax proposals ignore this problem, implicitly denying any transition relief for tax rate changes. To the extent we are 
concerned about the transition effects, David Bradford proposed an economic equivalent to a cash flow system that uses basis, and, therefore, alleviates transition effects from tax rate changes. ${ }^{60}$ This system could be adopted if needed, although it is much more complex than a cash flow system.

\section{Interest deductions}

The plan would deny interest deductions. While debt issued after the enactment of the plan can take this into account, debt issued previously cannot. Denial of interest deductions on existing debt may make many loans non-economic, possible forcing creditors to restructure their debt, a process that may be expensive and difficult. In the worst case, some creditors could be forced into bankruptcy. Given the volume of outstanding loans, this is not a small problem.

One possibility is to grandfather debt issued prior to the effective date of the law. The problem with this approach is that debt can be outstanding for very long periods of time. Treating old debt and new debt differently for long periods of time would be complex. Moreover, if old debt gets better treatment than new debt, businesses will have a tax incentive to keep old debt rather than issue new debt even economically this is not desirable.

The Bush commission recommended a five-year phase-out of interest expense deductions, similar to their phase-out of depreciation deductions. Under this approach, interest deductions on all debt, regardless of when issued, are reduced gradually. The effect in each year would be the same as a $20 \%$ reduction in tax rates, and businesses have experienced tax rate changes of this size in the past without large disruptions. The tax plan introduced by Devin Nunes in H.R. 4377 (cited in the Brady plan) takes a similar approach. This approach is preferable to grandfathering old debt because it means we do not have to have dual tax systems running indefinitely, which we would need if old debt were grandfathered.

\section{Border adjustments ${ }^{61}$}

As noted, it will be important to manage the transition to border adjustments so that importers are not adversely affected. Recall the

${ }^{60}$ David F. Bradford, Transition to and Tax-Rate Flexibility in a CashFlow-Type Tax, 12 TAX POL. \& ECON. 151 (1998).

${ }^{61}$ My focus here is limited to issues of implementation. Note, however, that the currency price changes on transition to a destination basis may have substantial economic effects. In particular, U.S. holdings of foreign assets would decline in value and foreign holdings of U.S. assets would appreciate. Together, these changes would represent a net wealth loss to U.S. citizens. CARROLL AND VIARD, supra note 16 at 110-111, provide a discussion. 
illustration used above: a firm that purchases goods from abroad for $\$ 95$ and sells them domestically for $\$ 100$. Under current law, the firm would be taxed on its $\$ 5$ profit. The $\$ 95$ purchase price would be effectively deductible against its $\$ 100$ sale proceeds (through basis rather than a deduction but the effect is the same). Under a destinationbased tax, the firm would no longer be able to deduct the $\$ 95$ purchase price and would owe a tax on the full $\$ 100$ sales proceeds. The tax could easily exceed its profit.

As noted, economists argue that currency prices will adjust so that the firm's position remains unchanged. For example, if the dollar appreciates, the firm could buy the same good for $\$ 76$, pay a $\$ 20$ tax and still be left an after-tax profit of $\$ 4$ (which can be thought of as a $\$ 5$ pre-tax profit less a $20 \%$ tax). One immediate problem is that if the purchase contract is denominated in dollars, the price would not change when dollars appreciate. This means that dollar-denominated purchase contracts would have to be renegotiated. Like with debt instruments, renegotiation could take time so that a phase-in of border adjustments may be warranted.

The Bush commission also argued for a phase-in of border adjustments. The basic idea is that a small border adjustment induces only a small currency price effect. If the currency price effect is slow or incomplete, the harm to importers is modest. This idea is worth considering. A problem is that currency markets may anticipate the phase-in and force the dollar to appreciate faster than the phase-in. In this case, exporters would be hurt.

\section{CONCLUSIONS}

Implementing a tax system based on the Brady plan will present a substantial challenge. Many implementation problems arise because nothing like this has ever been tried by a developed country, not to speak of in a country the size of the United States. It is likely that over time, solutions to most issues will be found. Given the substantial number of issues, however, it is naïve to think that the plan can be passed into law quickly.

Some issues, such as correcting the treatment of land and inventory are straightforward. Others, such as the elimination of the regimes for pass-through taxation and rules for major corporate transactions, are conceptually straightforward but will be involve more substantial changes to current law. And others will be difficult. Among the most important and difficult issues are the following:

- Deferral and the collection of the capital income tax on individuals. 
- The legality of border adjustments and possible design changes to improve the odds of compliance with the GATT.

- The treatment of financial institutions.

- The treatment of businesses that consistently generate tax losses while making economic profits.

- Distinguishing between real and financial flows, and making a consistent choice to have an R-based system (or an R+F system).

- Transition.

These issues do not have straightforward solutions and will need careful analysis as the legislative process moves forward. 